\title{
On the meridional ageostrophic transport in the tropical Atlantic
}

\author{
Yao Fu ${ }^{1, *}$, Johannes Karstensen ${ }^{1}$, and Peter Brandt ${ }^{1,2}$ \\ ${ }^{1}$ GEOMAR Helmholtz Centre for Ocean Research Kiel, Kiel, Germany \\ ${ }^{2}$ Christian-Albrechts-Universität zu Kiel, Kiel, Germany \\ * Invited contribution by Yao Fu, recipient of the EGU Ocean Sciences Outstanding Student Poster Award 2015.
}

Correspondence to: Yao Fu (yfu@geomar.de)

Received: 9 December 2016 - Discussion started: 9 January 2017

Revised: 8 May 2017 - Accepted: 25 May 2017 - Published: 6 July 2017

\begin{abstract}
The meridional Ekman volume, heat, and salt transport across two trans-Atlantic sections near $14.5^{\circ} \mathrm{N}$ and $11^{\circ} \mathrm{S}$ were estimated using in situ observations, wind products, and model data. A meridional ageostrophic velocity was obtained as the difference between the directly measured total velocity and the geostrophic velocity derived from observations. Interpreting the section mean ageostrophy to be the result of an Ekman balance, the meridional Ekman transport of $6.2 \pm 2.3 \mathrm{~Sv}$ northward at $14.5^{\circ} \mathrm{N}$ and $11.7 \pm 2.1 \mathrm{~Sv}$ southward at $11^{\circ} \mathrm{S}$ is estimated. The integration uses the top of the pycnocline as an approximation for the Ekman depth, which is on average about $20 \mathrm{~m}$ deeper than the mixed layer depth. The Ekman transport estimated based on the velocity observations agrees well with the predictions from in situ wind stress data of $6.7 \pm 3.5 \mathrm{~Sv}$ at $14.5^{\circ} \mathrm{N}$ and $13.6 \pm 3.3 \mathrm{~Sv}$ at $11^{\circ} \mathrm{S}$. The meridional Ekman heat and salt fluxes calculated from sea surface temperature and salinity data or from highresolution temperature and salinity profile data differ only marginally. The errors in the Ekman heat and salt flux calculation were dominated by the uncertainty of the Ekman volume transport estimates.
\end{abstract}

\section{Introduction}

In the tropical Atlantic Ocean, strong and steady easterly trade winds generate a poleward meridional flow in the surface layer. According to the classical linear theory of Ekman (1905), under the momentum balance between steady wind stress and Coriolis force, the wind-driven flow spirals clockwise with depth, the Ekman spiral, while the vertical integration of the spiral results in a net volume transport to the right of the wind direction (Northern Hemisphere), the Ekman transport. A convergence is created in the subtropics, where the poleward Ekman transport induced by the trade winds interacts with the equatorward Ekman transport induced by the mid-latitude westerlies. In simple linear vorticity theory, the Ekman convergence in subtropics drives an equatorward Sverdrup transport that explains many aspects of the wind-driven gyre circulation, such as the subtropical cells (STC). Schott et al. (2004) calculated the Ekman divergence $\left(21-24 \mathrm{~Sv}, 1 \mathrm{~Sv}=10^{6} \mathrm{~m}^{3} \mathrm{~s}^{-1}\right)$ between $10^{\circ} \mathrm{N}$ and $10^{\circ} \mathrm{S}$ in the tropical Atlantic using climatological wind to infer the strength of the STC; Rabe et al. (2008) further analysed the variability of the STC using the same sections based on assimilation products, and found that on timescales longer than 5 years to decadal, the variability of poleward Ekman divergence leads the variability of geostrophic convergence in the thermocline.

The meridional Ekman transport is, depending on the latitude, an important upper layer contribution when estimating the strength of the Meridional Overturning Circulation (MOC, Friedrichs and Hall, 1993; Klein et al., 1995; Wijffels et al., 1996). The variations in the meridional Ekman transport have been found to cause barotropic adjustment of the MOC in the ocean interior on different timescales. Cunningham et al. (2007) reported that the upper ocean had an immediate response to the changes in Ekman transport at subseasonal to seasonal timescales, while Kanzow et al. (2010) found that on the seasonal timescale, the Ekman transport was less important than the mid-ocean geostrophic transport, whose seasonal variation was dominated by the seasonal cycle of the wind stress curl. McCarthy et al. (2012) analysed a low MOC case during 2009 and 2010, and also pointed out that on the interannual timescale, although the Ekman transport played a role, its variability was relatively small compared to the variability in mid-ocean geostrophic transport, especially in the upper $1100 \mathrm{~m}$. 
Of interest for large-scale overturning studies are also the meridional Ekman-driven heat and freshwater fluxes that provide an important upper layer constraint, for example, for geostrophic end point arrays (McCarthy et al., 2015; McDonagh et al., 2015). In many cases, sea surface temperature (SST) has been found to be a sufficient constraint for the Ekman layer temperature (Wijffels et al., 1994; Chereskin et al., 2002). This probably is not too much of a surprise as the heat flux is primarily determined by the transport and less by the relatively small variability in temperature. However, the unresolved vertical structure of the water column could lead to an unknown bias, for example, due to the difference between the mixed layer depth (MLD) and the depth of the Ekman layer. An extreme case has been reported for the northern Indian Ocean at $8^{\circ} \mathrm{N}$ at the end of a summer monsoon event (Chereskin et al., 2002), where the direct Ekman temperature transport was $5 \%$ smaller when using the temperature within the top of the pycnocline (TTP, as a proxy of the Ekman layer depth) than using the SST, and the corresponding mean temperature in the Ekman layer was $1.1^{\circ} \mathrm{C}$ cooler than the averaged SST. In this case, the mean TTP depth was $92 \mathrm{~m}$ deeper than the mean MLD.

Assuming the upper layer ageostrophic flow in Ekman balance, the meridional Ekman transport $\left(M_{\mathrm{E}}^{y}\right)$ can be estimated indirectly from zonal wind stress data or directly from integrating observed ageostrophic Ekman velocity $\left(v_{\mathrm{E}}\right)$ :

$M_{\mathrm{E}}^{y}=\frac{1}{\rho} \frac{\tau_{x}}{f}=-\int_{-D_{\mathrm{E}}}^{0} v_{\mathrm{E}} \mathrm{d} z$,

where $\tau_{x}$ is the zonal wind stress, $\rho$ is the density of seawater, $f$ is the Coriolis parameter of the respective latitude, $D_{\mathrm{E}}$ is the Ekman depth, and $z$ is the upward vertical coordinate. $D_{\mathrm{E}}$ can be defined as the $e$-folding-scale depth of the Ekman spiral, leading to an analytical solution of $D_{\mathrm{E}}=\sqrt{\frac{2 A_{\mathrm{v}}}{f}}$, where $A_{\mathrm{v}}$ is a constant vertical eddy viscosity (Price et al., 1987). Ekman's solution also reveals a surface Ekman velocity $V_{0}=\frac{\tau}{\sqrt{\rho^{2} f A_{v}}}$, which is $45^{\circ}$ to the right (left) of the wind direction in the Northern (Southern) Hemisphere.

An ageostrophic velocity $\left(v_{\text {ageos }}\right)$ can be calculated as the difference of the directly observed velocity $\left(v_{\text {obs }}\right)$ and the geostrophic velocity ( $v_{\text {geos }}$ ). The ageostrophic velocity might consist of an Ekman component $\left(v_{\mathrm{E}}\right)$ and components that are not in Ekman balance (e.g. inertial currents). Often the non-Ekman components are assumed to be 0 , and $v_{\mathrm{E}}$ is expected to equal $v_{\text {ageos. }}$. Under this assumption, the Ekman velocity can be derived as follows:

$v_{\mathrm{E}}=v_{\text {obs }}-v_{\text {geos }}$.

Direct velocity profile data, for example from ADCP, and geostrophic velocities, from hydrographic data, are used in studies comparing direct with indirect Ekman transport estimates (e.g. Chereskin and Roemmich, 1991; Wijffels et al., 1994; Garzoli and Molinari, 2001). The Ekman transport is then derived from vertical integration of the $v_{\mathrm{E}}$.
For both equations it is relevant to recall that the Ekman balance is derived for an ocean with constant vertical viscosity and infinite depth, forced by a steady wind field (Ekman, 1905). Such conditions are not found in the real ocean; therefore, applications of the indirect (Eq. 1) and direct (Eq. 2) approaches suffer from different kinds of errors. For the indirect approach (Eq. 1) the temporally varying wind field, the momentum flux calculated from the wind speed, and the unknown partitioning of the wind energy input into the Ekman layer at different frequency bands are probably the most important sources of errors introduced into any Ekman current/transport estimate. For the direct approach, unknown lower integration depth, momentum flux variability, errors introduced by the experimental design (e.g. an shipboard ADCP does not resolve the upper 10-20 $\mathrm{m}$ of the flow, which is often assumed equal to the values at the first valid bin) or instrument errors can impact obtained results.

Many observational studies on Ekman dynamics that compare indirect and direct approaches have been conducted in the trade wind regions, where at least the wind stress forcing is relatively constant. Using shipboard ADCP data together with conductivity-temperature-depth (CTD) profile data, Chereskin and Roemmich (1991) directly estimated an Ekman transport of $9.3 \pm 5.5 \mathrm{~Sv}$ at $11^{\circ} \mathrm{N}$ in the Atlantic by integrating an ageostrophic velocity from the surface to a depth equivalent to TTP. The ageostrophic velocity was obtained by subtracting the geostrophic velocity from the ADCP velocity. Using a similar direct method, Wijffels et al. (1994) estimated an ageostrophic transport of $50.8 \pm 10 \mathrm{~Sv}$ at $10^{\circ} \mathrm{N}$ in the Pacific. Chereskin et al. (1997) found Ekman transports of $-17.6 \pm 2.4$ and $-7.9 \pm 2.7 \mathrm{~Sv}$ during and after a southwest monsoon event at $8.5^{\circ} \mathrm{N}$ in the Indian Ocean, respectively. In all the above studies, the direct estimates agree within 10-20\% of the estimates obtained by using the in situ wind data (Eq. 1). Both the direct and indirect approaches also show a consistent transport structure across all the basins, which can be seen from the cumulative meridional Ekman transport curves from one boundary to the other. An indication of the existence of an Ekman balance in the upper ocean is the occurrence of an Ekman spiral. In all the above publications an "Ekman spiral"-like feature has been identified. Because $v_{\text {geos }}$ can be estimated only perpendicularly to the CTD stations and all studies are based on more or less zonal CTD sections, the three-dimensional structure of the Ekman spiral can not be obtained. However, the Ekman flow becomes evident by a near-surface maximum of the meridional ageostrophic velocity decreasing smoothly below within the upper $50-100 \mathrm{~m}$ to zero.

Despite the fact that the zonal wind in the above studies was predominantly uniform in one direction, their ageostrophic velocity showed a pattern of alternating currents. Also, the section-averaged ageostrophic velocity profiles often exhibited structures that are not a result of an Ekman balance. Chereskin and Roemmich (1991) reported signals of internal wave propagation that was responsible for a 
peak in their section-integrated ageostrophic transport profile below the Ekman layer. Garzoli and Molinari (2001) also reported on vertically alternating structures in the sectionaveraged ageostrophic velocity profile at $6^{\circ} \mathrm{N}$ in the Atlantic. They proposed several possible candidates that could contribute to creating this structure, such as inertial currents within the latitude range of the North Equatorial Counter Current (NECC), and tropical instability waves with northward and southward velocities. Besides, they argued that the advective terms in the momentum equations might also produce a large non-Ekman ageostrophic transport in the presence of large horizontal shears between the NECC and the northern branch of the South Equatorial Current (nSEC).

The appearance of these non-Ekman ageostrophic currents is not surprising, since it has been long recognized that the temporal variability of the wind field leads to wind energy input into the Ekman layer at subinertial and near-inertial frequencies. Wang and Huang (2004) estimated the global wind energy input into the Ekman layer at subinertial frequencies (frequency lower than 0.5 cycles per day) to be $2.4 \mathrm{TW}$, while Watanabe and Hibiya (2002) and Alford (2003) estimated that at near-inertial frequencies the wind energy input was 0.7 and $0.5 \mathrm{TW}$, respectively. Elipot and Gille (2009) estimated the wind energy input into the Ekman layer for the frequency range between 0 and $2 \mathrm{cpd}$ at $41^{\circ} \mathrm{S}$ in the Southern Ocean using surface drifter data. They found that the nearinertial input (between $0.5 f$ and $2 \mathrm{cpd}$ ) contributes $8 \%$ of the total wind energy input (here the "total" means the frequency range between 0 and $2 \mathrm{cpd}$ ), which may still underestimate the near-inertial contribution due to limitations in their data. All these studies suggest that at least about $10 \%$ of the wind energy (frequency range between 0 and $2 \mathrm{cpd}$ ) into the Ekman layer is at near-inertial frequencies, which is used to supply the non-Ekman ageostrophic motions (inertial oscillation, near-inertial internal waves, etc.). Therefore, complicated structures in the directly observed ageostrophic velocity as reported by Chereskin and Roemmich (1991) and Garzoli and Molinari (2001) can be anticipated.

The purpose of the present study is to estimate the Ekman volume, heat, and freshwater transport across two transAtlantic sections nominally along $14.5^{\circ} \mathrm{N}$ and $11^{\circ} \mathrm{S}$ by using direct and indirect methods, and to analyse the vertical structure of the ageostrophic flow by using high-resolution velocity and hydrographic data. In previous studies, the geostrophic velocity was estimated using CTD profile data with a station spacing of approximately $30-60 \mathrm{~nm}$, and only in situ and climatological wind data were available. In this study, we apply the recently introduced underway-CTD (uCTD), which allows profiling with denser station spacing of about $8-10 \mathrm{~nm}$ or less and does not require additional station time by measuring from moving ships (e.g. volunteer commercial and research vessels). We first describe the processing of the uCTD data in detail, and then apply the uCTD data to calculate the Ekman transport. We also test the sensitivity of the Ekman transport estimates with respect to the
CTD profile resolution. We then apply wind data from different sources to indirectly estimate the Ekman transport, including the in situ (ship) wind, satellite-based wind product, and reanalysis wind products. In order to integrate the observation-based Ekman transport estimates into the largescale tropical Atlantic context, we compared our results with the GECCO2 ocean synthesis data. This work is structured as follows: the processing of the data is described in Sect. 2. The methods used in the calculation of Ekman volume, heat, and salt transport are described in Sect. 3. The vertical and horizontal structures of the ageostrophic velocity, together with the Ekman volume, heat, and salt transport estimated using different datasets and different methods are presented and discussed in Sect. 4, followed by a summary in Sect. 5 .

\section{Data}

Two trans-Atlantic zonal sections near $14.5^{\circ} \mathrm{N}$ and $11^{\circ} \mathrm{S}$ were occupied by R/V Meteor on three cruise legs (M96, M97, and M98). The $14.5^{\circ} \mathrm{N}$ section began with cruise M96 off the coast of Trinidad and Tobago on 28 April 2013. The section ended on M96 at about $20^{\circ} \mathrm{W}$ on 20 May, and was continued to the African coast during M97 from 8 to 9 June (Fig. 1). During these surveys, 64 CTD stations were conducted along the $14.5^{\circ} \mathrm{N}$ section, with an average spacing of $40 \mathrm{~nm}(75 \mathrm{~km})$. Parallel to the CTD system, the uCTD system was operated between the adjacent CTD stations when the ship was steaming at $10-12 \mathrm{kn}$. In total, $317 \mathrm{uCTD}$ profiles were achieved, with an average spacing of $8 \mathrm{~nm}(15 \mathrm{~km})$. The $11^{\circ} \mathrm{S}$ section was surveyed during M98 from 6 to 23 July 2013. In this section, the standard CTD was only operated on the shelf and at the shelf break; during the transit across the Atlantic, only the uCTD was in use. All together, $290 \mathrm{uCTD}$ profiles were taken during the survey, with an average spacing of $11 \mathrm{~nm}(20 \mathrm{~km})$. Shipboard ADCP and anemometer were in continuous operation through the entire cruises.

\subsection{CTD and uCTD measurements}

The CTD work was carried out with a Sea-Bird Electronic (SBE) 9 plus CTD system. The two temperature sensors were calibrated at the manufacturer just before cruise M96 in March 2013. The conductivity measurements were calibrated by comparing the bottle stop data with salinometer measurements of bottle samples. All CTD system quality control procedures followed the GO-SHIP recommendations (Hood et al., 2010). The accuracy of the CTD data was estimated to be $\pm 0.001{ }^{\circ} \mathrm{C}$ for temperature and $\pm 0.002 \mathrm{~g} \mathrm{~kg}^{-1}$ for salinity.

The uCTD system used at both zonal sections was an Oceanscience Series II underway-CTD. It consisted of a probe, a tail, and a winch. The probe is equipped with a temperature (SBE-3F), a conductivity (SBE-4) and a pressure sensor from SBE. A tail spool reloading system allows the rope spooled on the tail to be paid out when the probe falls 


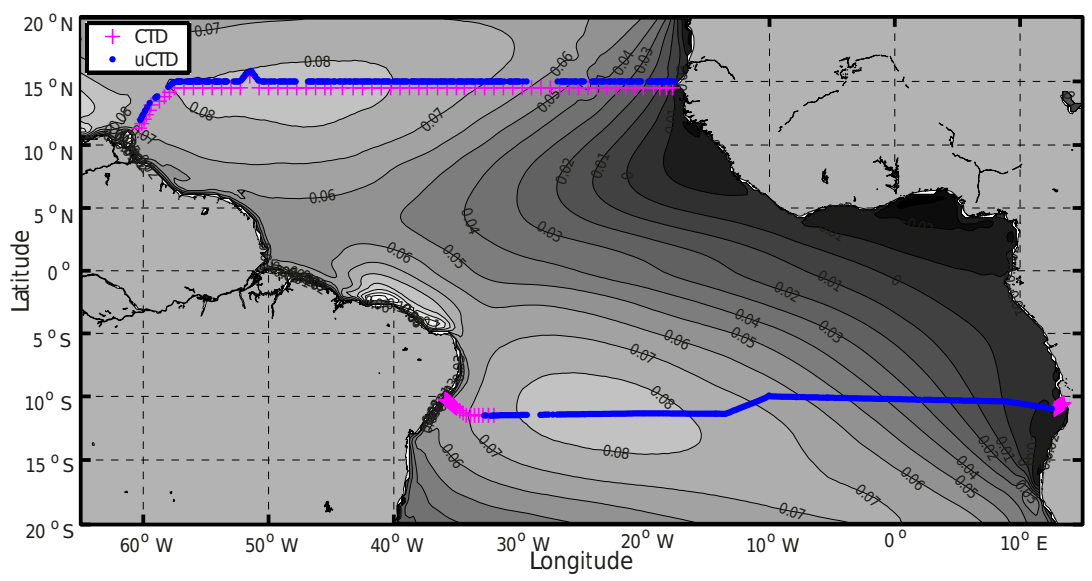

Figure 1. Positions of the CTD (magenta + ) and uCTD (blue dots) measurements along the $14.5^{\circ} \mathrm{N}$ and $11^{\circ} \mathrm{S}$ sections. The $14.5^{\circ} \mathrm{N}$ section was completed during RV Meteor cruises M96 (28 April to 20 May 2013, west of $20^{\circ} \mathrm{W}$ ) and M97 (8 to 9 June 2013 , east of $20^{\circ} \mathrm{W}$ ), the $11^{\circ} \mathrm{S}$ section during M98 (6 to 23 July 2013). Note that the uCTD position for the $14.5^{\circ} \mathrm{N}$ section is artificially shifted to the north by $0.5^{\circ}$ for visual clarity. The grey shading with contours is the mean zonal wind stress calculated from NCEP/CFSr monthly wind stress between 1979 and 2011 in $\mathrm{Nm}^{-2}$.

Table 1. Meridional Ekman volume ( $M^{y}$ in Sv), heat $\left(H_{\mathrm{e}}\right.$ in PW), and salt $\left(S_{\mathrm{e}}\right.$ in $\left.10^{6} \mathrm{~kg} \mathrm{~s}^{-1}\right)$ fluxes calculated using different methods, and the transport-weighted temperature $\Theta_{\mathbf{E}}$ and salinity $S_{\mathrm{AE}}$ in the Ekman layer. Positive and negative fluxes denote northward and southward fluxes, respectively. The uncertainties of the Ekman heat and salt flux are $0.4 \mathrm{PW}$ and $45 \times 10^{6} \mathrm{~kg} \mathrm{~s}^{-1}$ at $14.5^{\circ} \mathrm{N}$, and $0.3 \mathrm{PW}$ and $65 \times 10^{6} \mathrm{~kg} \mathrm{~s}-1$ at $11^{\circ} \mathrm{S}$, respectively. The uncertainties of the transport-weighted Ekman temperature and salinity are $0.20^{\circ} \mathrm{C}$ and $0.15 \mathrm{~g} \mathrm{~kg}^{-1}$ at $14.5^{\circ} \mathrm{N}$, and $0.11^{\circ} \mathrm{C}$ and $0.10 \mathrm{~g} \mathrm{~kg}^{-1}$ at $11^{\circ} \mathrm{S}$, respectively.

\begin{tabular}{|c|c|c|c|c|c|c|c|c|c|c|c|c|}
\hline & & & \multicolumn{10}{|c|}{ Section } \\
\hline & & & \multicolumn{5}{|c|}{$14.5^{\circ} \mathrm{N}$} & \multicolumn{5}{|c|}{$11^{\circ} \mathrm{S}$} \\
\hline & & & $\Theta_{\mathrm{E}}$ & $S_{\mathrm{AE}}$ & $M^{y}$ & $H_{\mathrm{e}}$ & $S_{\mathrm{e}}$ & $\Theta_{\mathrm{E}}$ & $S_{\mathrm{AE}}$ & $M^{y}$ & $H_{\mathrm{e}}$ & $S_{\mathrm{e}}$ \\
\hline \multirow{5}{*}{$\begin{array}{l}\vec{D} \\
\frac{D}{0} \\
\stackrel{\mathbb{E}}{\Sigma}\end{array}$} & & TTP/profile & 25.52 & 36.33 & 6.21 & 0.413 & 5.40 & 25.41 & 36.83 & -11.71 & -0.842 & -17.69 \\
\hline & Direct & TTP/surface & 25.61 & 36.34 & 6.21 & 0.415 & 5.49 & 25.41 & 36.80 & -11.71 & -0.842 & -17.38 \\
\hline & & TTP & 25.46 & 36.32 & 6.68 & 0.443 & 5.72 & 25.13 & 36.81 & -13.64 & -0.965 & -20.50 \\
\hline & Indirect & Surface & 25.65 & 36.29 & 6.68 & 0.448 & 5.57 & 25.20 & 36.78 & -13.64 & -0.946 & -20.04 \\
\hline & & Annual & 26.46 & 36.13 & 8.31 & 0.584 & 5.56 & 25.53 & 36.73 & -11.02 & -0.799 & -15.49 \\
\hline
\end{tabular}

freely. The sensors record data at a frequency of $16 \mathrm{~Hz}$. For most of the profiles about $250-300 \mathrm{~m}$ of rope were spooled on the tail spool (which set the fall depth) and the recording time length was set to $100 \mathrm{~s}$, and about 1600 data recordings per cast were obtained. From the tail spool the probe sinks freely with a nominal speed of $4 \mathrm{~m} \mathrm{~s}^{-1}$. However, due to the back-and-forth unspooling of the rope from one end of the tail to the other, the sinking speed typically varies from 3 to $4.5 \mathrm{~m} \mathrm{~s}^{-1}$. After the rope on the tail is paid out completely, the probe still sinks at speeds less than $2 \mathrm{~m} \mathrm{~s}^{-1}$ in the last tens of metres of its sinking before being winched back to the ship and recovered back to deck. Three probes were used during the two section surveys (nos. 70200126 and 70200068 along the $14.5^{\circ} \mathrm{N}$ section; nos. 70200068 and 70200138 along the $11^{\circ} \mathrm{S}$ section). The uCTD winches were out of service several times during the three cruise legs. Although they were repaired on-board, several measurement gaps were left, for example, between 29 and $27^{\circ} \mathrm{W}$ (Fig. 1).

The post-calibration of the uCTD data was done in two major steps: the first step is a sensor calibration procedure, which corrects the temperature sensor error due to viscous heating, the conductivity sensor error due to thermal mass delay, and the lag between the conductivity and temperature sensors; the second step is data validation in reference to CTD profile data and to thermosalinograph (TSG) data. The first step was done following Ullman and Hebert (2014) (hereafter UH2014). We will briefly describe the process here; for details, please refer to their work. The uCTD is an unpumped CTD system, the rapid sinking speed of $4 \mathrm{~m} \mathrm{~s}^{-1}$ allowing water to pass through the sensor package at $3.56 \mathrm{~m} \mathrm{~s}^{-1}$ (UH2014). This flow rate is much higher than a pumped CTD system $\left(1 \mathrm{~m} \mathrm{~s}^{-1}\right)$, which leads to a clear viscous heating effect of the uCTD temperature sensor. This was 
corrected using a steady-state result of Larson and Pedersen (1996) for the perpendicular flow case (cf. Eq. 8 of UH2014). The thermal mass correction was performed following the algorithm of Lueck and Picklo (1990) and using the mean values of error magnitude and time constant from UH2014 (cf. Table 1 of UH2014).

From the uCTD profiles alone a time lag correction was determined from cross-correlation of temperature and conductivity sensor small-scale variability. The variability was calculated by subtracting a sixth-order Butterworth low-pass filtered profile with a cut-off frequency of $4 \mathrm{~Hz}$ from the corresponding temperature and conductivity time series of each profile. The highest correlation was found for a $1 / 16 \mathrm{~s}$ lag (conductivity leading), which equals the sampling frequency of $16 \mathrm{~Hz}$ data. Application of the lag eliminated most of the spikes in the salinity profiles when the sinking speed of the probe was above about $1.5 \mathrm{~m} \mathrm{~s}^{-1}$. However, when the sinking speed was below $1.5 \mathrm{~m} \mathrm{~s}^{-1}$, this correction would cause the spikes pointing in the opposite direction and indicates an inverse dependency of the lag on the sinking speed. This result is consistent with that reported by UH2014, and we corrected the lag following their lag model (cf. Eq. 7 of UH2014), but adjusted their parameters to match our data. The data recorded with a sinking speed smaller than $0.3 \mathrm{~m} \mathrm{~s}^{-1}$ were neglected (including all upcast data).

Validation of the lag corrected UCTD against CTD profile data revealed for the $14.5^{\circ} \mathrm{N}$ section a drift in the conductivity sensors of uCTD probes nos. 70200126 and 70200068 . A bias correction in the sense of an absolute salinity offset (uCTD-CTD) was determined based on the temperaturesalinity space (Rudnick and Klinke, 2007) by considering the conservative temperature range from 12 to $14^{\circ} \mathrm{C}$ and using all uCTDs between adjacent CTD pairs. This particular temperature range was chosen because it belongs to the Atlantic central water, whose $T / S$ relation is nearly linear, which implies that in this temperature range, the spreading of salinity measured during different uCTD casts should be tight. Besides, it was also surveyed by almost all uCTD casts along the section. For probe no. 70200126, the salinity offset fluctuates around a mean value of $0.038 \mathrm{~g} \mathrm{~kg}^{-1}$ west of $39^{\circ} \mathrm{W}$ (CTD station 34), east of which the offset shifts abruptly to around $0.151 \mathrm{~g} \mathrm{~kg}^{-1}$. The calibration was done by applying the mean offset values to the salinity data in the corresponding groups of uCTDs. The salinity data of the last few profiles of probe no. 70200126 (between 30 and $29^{\circ} \mathrm{W}$ ) were extremely noisy, and not possible to calibrate. This probe was not further used during the rest of the section due to its poor quality of the salinity data. For probe no. 70200068, the salinity offset remains around 0 west of $36^{\circ} \mathrm{W}$ (CTD station 38 ), and then abruptly shifts to around $0.295 \mathrm{~g} \mathrm{~kg}^{-1}$ between 36 and $23.5^{\circ} \mathrm{W}$ (CTD station 56). East of $23.5^{\circ} \mathrm{W}$ to the African coast, the offset shows a linear decreasing trend. This is likely due to the increasing portion of South Atlantic central water (SACW) in the central water layer when approaching the coastal region, which is less saline than the North At- lantic central water (NACW), and consequently shifting the slope of the $T / S$ curve. As a result, the linear trend of the offset east of $23.5^{\circ} \mathrm{W}$ should not be due to instrument error. Therefore, only a mean offset was calculated and applied to calibrate each corresponding group of profiles made by no. 70200068. The reasons for the abrupt drift in the salinity (as obtained from the conductivity sensors) are not clear, but it is likely that due to the repeated intensive usage, the conductivity sensors were contaminated or impacted (hit ship hull).

The shipboard TSG provides another source of validation and calibration of uCTD data. On R/V Meteor, the TSG (SBE38 for temperature sensor, SBE21 for conductivity sensor) measures temperature and salinity at an intake at approximately $6.5 \mathrm{~m}$ depth. For all three legs, the TSG conductivity cell was calibrated from salinity analysis of water samples taken at the water intake, and a comparison with CTD data (if available) was also done. The uCTD salinity calibration was done by calculating the conductivity offset between the UCTD at $6.5 \mathrm{~m}$ and the averaged TSG conductivity within $5 \mathrm{~min}$ before and after the uCTD downcast. For probe no. 70200126 , the drift of its conductivity sensor manifests also east of $39^{\circ} \mathrm{W}$, the conductivity offset west of $39^{\circ} \mathrm{W}$ is about $-0.022 \mathrm{~S} \mathrm{~m}^{-1}$, and east of that it is about $0.094 \mathrm{~S} \mathrm{~m}^{-1}$. These differences in conductivity correspond to a change in salinity of -0.015 and $0.08 \mathrm{~g} \mathrm{~kg}^{-1}$, respectively. For probe no. 70200068, the conductivity offset west of $36^{\circ} \mathrm{W}$ is indistinguishable from zero, while east of that it is $0.156 \mathrm{~S} \mathrm{~m}^{-1}$, which corresponds to a salinity difference of 0 and $0.15 \mathrm{~g} \mathrm{~kg}^{-1}$. No trend in the offset east of $23.5^{\circ} \mathrm{W}$ is detected. For the $14.5^{\circ} \mathrm{N}$ section, we had uCTD, CTD, and TSG data available and the respective calibrations uCTD/CTD and uCTD/TSG could be compared. This was done in order to see if in case only TSG data are available (as is the case for the $11^{\circ} \mathrm{S}$ section), still reasonable calibration results could be achieved. For both probes, the TSGderived drifts occurred in the same longitude range as they were detected using the CTD data. However, the magnitude of the offset was generally smaller for the TSG compared to the CTD-based method, especially for probe no. 70200126 in the longitude range west of $39^{\circ} \mathrm{W}$, where even the signs of the offsets were opposite to each other. Such a difference is likely due to the fact that the CTD-based method employs a specific conservative temperature range where the salinity variation is small, while the TSG-based method focuses only at near-surface values $(6.5 \mathrm{~m})$, where the salinity varies in a broad range. Therefore, we would trust more the CTDbased method, and note that if the TSG-based method returns a small conductivity offset $\left(<0.03 \mathrm{~S} \mathrm{~m}^{-1}\right)$, one might need more caution to apply this offset to calibrate the uCTD. However, one needs also more caution when applying the CTD-based calibration in regions, where the $T / S$ relation of the central water shows a mixture effect of NACW and SACW. At the $11^{\circ} \mathrm{S}$ section, CTD data were only available at the beginning and end of the section; we could use only the TSG data as the primary source for validation. Fortu- 
nately no drift was detected in the uCTD probes' conductivity cell, but a stable offset with a mean value of 0.131 and $0.073 \mathrm{~S} \mathrm{~m}^{-1}$ was detected and applied for probes nos. 70200068 and 70200138 , respectively.

After the offset/drift calibration, all the uCTD data were gridded vertically from the original resolution $(\sim 0.25 \mathrm{~m}$ at a nominal sinking speed of $4 \mathrm{~m} \mathrm{~s}^{-1}$ ) to $1 \mathrm{~m}$ for the geostrophic velocity calculation later. Following Rudnick and Klinke (2007), we estimated that the calibrated and gridded uCTD data have an accuracy of $0.02-0.05 \mathrm{~g} \mathrm{~kg}^{-1}$ in salinity and $0.004^{\circ} \mathrm{C}$ in temperature.

All calculations in this study are based on the Thermodynamic Equation of State for seawater 2010 (TEOS-10, McDougall and Barker, 2011). TEOS-10 is introduced to replace the previous Equation of State, EOS-80, and it provides a thermodynamically consistent definition of the equation of state in terms of the Gibbs function for seawater. The most obvious change in TEOS-10 is the adoption of conservative temperature $(\Theta)$ and absolute salinity $\left(S_{\mathrm{A}}\right)$ to replace the potential temperature and practical salinity. Although the new equation of state has a non-negligible effect on the density field in the deep ocean, its effect in the upper ocean is expected to be small; therefore, our results obtained using TEOS-10 should be comparable with the previous studies.

\subsection{ADCP measurements}

Direct current velocity profiles were measured continuously during all three cruise legs with vessel-mounted 75 and $38 \mathrm{kHz}$ Teledyne RDI Ocean Surveyors (OS75 and OS38). The OS75 was configured to measure at a rate of $2.2 \mathrm{~s}$ and a bin size of $8 \mathrm{~m}$. The measurement range varied between 500 and $700 \mathrm{~m}$. The OS38 was set to measure at a rate of $3.5 \mathrm{~s}$ and at $16 \mathrm{~m}(32 \mathrm{~m})$ bin size during the $14.5^{\circ} \mathrm{N}\left(11^{\circ} \mathrm{S}\right) \mathrm{sec}-$ tion. The measurement range was mostly $1200 \mathrm{~m}$. Ship navigation information was synchronized to the ADCP system. The misalignment angles and amplitude factors were calibrated during post-processing. The processed data contain $10 \mathrm{~min}$ averaged absolute velocities in earth coordinates; the first valid bin for OS75 is centred at $18 \mathrm{~m}$ at $14.5^{\circ} \mathrm{N}$ and $13 \mathrm{~m}$ at $11^{\circ} \mathrm{S}$, for OS38 is $21 \mathrm{~m}$ at both sections. In this study, only the OS75 velocity was used since it has a higher accuracy in upper layers and higher vertical resolution. The uncertainties of $1 \mathrm{~h}$ averages were estimated by Fischer et al. (2003) to be $1-3 \mathrm{~cm} \mathrm{~s}^{-1}$.

\section{Wind data}

We used three different wind datasets in our analysis. First, we used the observed wind speed and direction recorded with the R/V Meteor anemometer, mounted at a height of $35.3 \mathrm{~m}$. The wind data were stored with a temporal resolution of $1 \mathrm{~min}$. True wind speed and direction were calculated using ship speed and direction from the navigation system. On-station measurements were removed. The reduction from the observation height to $10 \mathrm{~m}$ standard height was calculated according to Smith (1988) and wind stress was calculated according to Large and Yeager (2004) assuming neutral stability. The final wind stress used for the Ekman transport calculation was binned in $50 \mathrm{~km}$ ensembles to filter out small-scale variability.

The blended Satellite-based level-4 Near-Real-Time wind stress product (hereafter satellite wind stress) from the Copernicus Marine Environment Monitoring Service (CMEMS) was used. The wind speed data are derived from retrievals of scatterometers aboard satellite METOPA (ASCAT) and Oceansat-2 (OSCAT) and combined with the European Centre for Medium-Range Weather Forecasts (ECMWF) operational wind analysis and gridded to $0.25^{\circ} \times 0.25^{\circ}$ resolution in space and $6 \mathrm{~h}$ in time. The wind stress data were estimated using the COARE 3 model (Fairall et al., 2003).

Moreover, the NCEP/NCAR monthly zonal wind stress at $14.5^{\circ} \mathrm{N}$ and $11^{\circ} \mathrm{S}$ corresponding to the months of the cruises (i.e. May and July 2013) was used to calculate the Ekman transport.

\subsection{GECCO2 ocean synthesis data}

In order to integrate our local observational results into a large-scale circulation, the GECCO2 ocean synthesis data were used and compared (Köhl, 2015). GECCO2 is a German version of the MIT general circulation model "Estimating the Circulation and Climate of the Ocean system" (ECCO, Wunsch and Heimbach, 2006). It has $1^{\circ} \times \frac{1}{3}^{\circ}$ resolution and 50 vertical levels. GECCO2 includes the Arctic Ocean with roughly $40 \mathrm{~km}$ resolution and a dynamic/thermodynamic sea ice model of Zhang and Rothrock (2000). The synthesis uses the adjoint method to bring the model into consistency with available hydrographic and satellite data (Köhl, 2015). The prior estimate of the atmospheric state is included by adjusting the control vector, which consists of the initial conditions for the temperature and salinity, surface air temperature, humidity, precipitation and the $10 \mathrm{~m}$ wind speeds from the NCEP RA1 reanalysis 1948-2011 (Köhl, 2015). The surface fluxes are derived by the model via bulk formulae of Large and Yeager (2004). For the study period from May to July 2013 monthly and daily output data were available. It is important to note that the in situ observational data measured during the cruises were not assimilated in the synthesis, while the satellite measured wind speed was assimilated but possibly modified via the synthesis.

\section{Methods}

According to Eqs. (1) and (2), the meridional Ekman volume transport can be calculated from zonal wind stress data, as well as from observed ageostrophic velocity. Hereafter 
we refer to the wind-stress-based calculation as the "indirect method", and to the ageostrophic-velocity-based calculation as the "direct method". In this section, we describe some details of the geostrophic and ageostrophic velocity calculation, the definition of the penetration depth of the Ekman flow, the error estimate of the direct Ekman transport calculation, and different methods to derive the Ekman heat and salt fluxes.

\subsection{Geostrophic and ageostrophic velocity calculations}

According to the thermal wind relation, relative geostrophic velocity referenced to the velocity at the reference depth can be calculated from the density field measured by the CTD and uCTD. At $14.5^{\circ} \mathrm{N}$, two sets of the relative geostrophic velocity were calculated independently from the CTD and uCTD datasets. For CTDs, the relative geostrophic velocity referenced to $200 \mathrm{~m}$ was computed between the adjacent stations (average distance about $75 \mathrm{~km}$ ). For uCTDs, in order to take advantage of the high spatial resolution, the relative geostrophic velocity to $200 \mathrm{~m}$ was calculated between any closest pair of uCTD profiles with a minimum distance of $70 \mathrm{~km}$ (roughly the Rossby radius of deformation at this latitude). Along the $11^{\circ} \mathrm{S}$ section, CTD profiles were only taken in the vicinity of the coasts, and over most of the section only uCTD data are available (Fig. 1). Therefore the geostrophic velocity was computed from the combined CTD and UCTD dataset following the methodology applied to uCTD data at the $14.5^{\circ} \mathrm{N}$ section, except that at $11^{\circ} \mathrm{S}$ the minimum distance between the closest profiles was set to $90 \mathrm{~km}$ (roughly the Rossby radius of deformation at $11^{\circ} \mathrm{S}$ ). Note that the distance between uCTD profiles for geostrophic velocity calculation is an arbitrary choice, and varying the distance from 70 to $110 \mathrm{~km}$ has a negligible effect on the total transport (less than $2 \%$ ).

To obtain the absolute geostrophic velocity, the reference velocity at $200 \mathrm{~m}$ was obtained from the ADCP measurement. The ADCP velocity was projected to the normal direction of the cruise track and then averaged between the corresponding CTD/uCTD pairs. We did not include the ADCP velocity data recorded at the CTD stations, because velocity was repeatedly measured at a CTD station; zonally averaging the ADCP velocity would bias the result towards the on-station velocity. In previous studies (Wijffels et al., 1994; Chereskin et al., 1997; Garzoli and Molinari, 2001), the corresponding ADCP velocity at the reference depth was taken as the reference velocity, assuming that the flow at the reference depth was in geostrophic balance. However, the section-averaged ADCP velocity profile for the $14.5^{\circ} \mathrm{N}$ section shows a complicated vertical structure (Fig. 3a) and it is not obvious at which depth the flow is approximately in geostrophic balance. Thus, referencing the relative geostrophic velocity to the ADCP velocity only at a chosen depth may lead to a biased absolute geostrophic velocity. As a result, the ageostrophic velocity may be sensitive to the choice of the reference level. To overcome this problem, a reference velocity was calculated as an averaged offset between each relative geostrophic velocity and the corresponding ADCP velocity within a common depth range, over which the ageostrophic components are averaged to about 0 . This averaged offset should represent the absolute geostrophic velocity at the reference depth and is roughly independent of the vertical variation due to the ageostrophic components. At $14.5^{\circ} \mathrm{N}$, the common depth range for the CTD-based calculation is between 70 and $500 \mathrm{~m}$, which is expected to be below the surface Ekman layer and covered by both CTD and ADCP measurement. Due to the limitations in the maximum deployment depth, the uCTD-based calculation covers the depth range between 70 and $250 \mathrm{~m}$. At $11^{\circ} \mathrm{S}$ the depth range is between 100 and $300 \mathrm{~m}$, which should also be below the Ekman layer and was covered by the uCTD and ADCP measurement.

The ageostrophic velocity was then calculated as the difference between the ADCP velocity and the absolute geostrophic velocity. Note that the choice of the depth range still affects the reference velocity due to the vertical variation in the ADCP meridional velocity. For example, using a depth range between 70 and $250 \mathrm{~m}$ for the CTD-based calculation (same as the uCTD depth range) would decrease the final ageostrophic velocity by $0.44 \mathrm{~cm} \mathrm{~s}^{-1}$; using another depth range would not result in an absolute difference exceeding this value. This is much smaller compared to the uncertainty caused by using the ADCP velocity at a single depth as the reference velocity (up to $1.75 \mathrm{~cm} \mathrm{~s}^{-1}$ ), as can be anticipated from the section-averaged meridional ADCP velocity (Fig. 3a). The sensitivity of the absolute geostrophic velocity to the choice of the reference level was also tested at $14.5^{\circ} \mathrm{N}$. Changing the reference level from 150 to $250 \mathrm{~m}$ would make a change in the absolute geostrophic velocity indistinguishable from zero.

\subsection{Penetration depth of the Ekman flow}

Because the ocean is not homogenous, a control surface must be defined that characterizes the maximum penetration depth of the momentum flux into the upper ocean. One choice would be the MLD, which we defined as the depth where the density increased by $0.01 \mathrm{~kg} \mathrm{~m}^{-3}$ in reference to the value at $10 \mathrm{~m}$ (following Wijffels et al., 1994). Along both sections, the MLD is relatively shallow (on average $25.1 \mathrm{~m}$ at $14.5^{\circ} \mathrm{N}$ and $32.2 \mathrm{~m}$ at $11^{\circ} \mathrm{S}$ ), and as such unlikely a representative of $D_{\mathrm{E}}$ (Figs. 3 and 4). According to the Ekman theory, $D_{\mathrm{E}}$ for water at $14.5^{\circ} \mathrm{N}$ with a typical vertical eddy viscosity $A_{\mathrm{v}}$ of $0.02 \mathrm{~m}^{2} \mathrm{~s}^{-1}$ would be $33.1 \mathrm{~m}$ (see the definition of $D_{\mathrm{E}}$ in Eq. 1).

Alternatively a TTP has been defined as the shallowest depth at which the density gradient is larger than $0.01 \mathrm{~kg} \mathrm{~m}^{-4}$ (Wijffels et al., 1994). The TTP is typically deeper than the MLD and better defines the transition depth between wellmixed and stratified ocean, up to which the momentum from the wind is transferred (Chereskin et al., 2002). At some lo- 
cations along both sections we observed two homogenous layers of slightly different density and possibly a remnant of the seasonal mixed layer cycle. In these cases, the TTP depth was chosen as the deeper one of the depth that satisfies the density gradient criterion. Since TTP was defined based on a gradient criterion, it represents the bottom of a weakly stratified surface layer rather than a specific density surface. Along the $14.5^{\circ} \mathrm{N}$ section, the mean TTP depth is $45.8 \mathrm{~m}$ (Fig. 3a). At both ends of the section, the TTP coincides with the MLD and is relatively shallow, while in the remaining part of the $14.5^{\circ} \mathrm{N}$ section TTP is deeper than the MLD (Fig. 4c). Along the $11^{\circ} \mathrm{S}$ section, the mean TTP depth is $56.8 \mathrm{~m}$, and the TTP is deeper than the MLD throughout the section (Figs. $3 b$ and $4 d$ ).

\subsection{Error estimate of the direct Ekman transport}

The errors of the direct Ekman transport were estimated following Chereskin and Roemmich (1991) and Wijffels et al. (1994). Assuming that near-inertial motions are the dominant source of error, decorrelation length scales were calculated as the distance that the ship travelled in a quarter of the inertial period at $14.5^{\circ} \mathrm{N}(47.9 \mathrm{~h})$ and $11^{\circ} \mathrm{S}(62.7 \mathrm{~h})$ resulting in 130 and $230 \mathrm{~km}$, respectively. In total, 38 segments of the $14.5^{\circ} \mathrm{N}$ section and 25 segments of the $11^{\circ} \mathrm{S}$ section were obtained by dividing the total distance of each section by the corresponding decorrelation length scale, respectively. The westernmost and easternmost four segments of each section were omitted because of the anomalously weak wind near the eastern boundary and the strong boundary current in the western boundary region. The degree of freedom (DOF) of 30 and 17, respectively, was the number of the remaining segments. The ageostrophic transport within each segment was treated as an independent realization of the Ekman transport. Therefore, standard errors were calculated. Then the final error is given as the standard error times the DOF. Another factor that could lead to an uncertainty is the depth range used to calculate the reference velocity from the ADCP velocity. As discussed above, we argue that the vertical structure of the ageostrophic velocity should arise from the near-inertial motion and therefore, should be included already in this uncertainty estimate.

\subsection{Ekman heat and salt flux calculation}

The Ekman heat and salt fluxes, $H_{\mathrm{e}}$ and $S_{\mathrm{e}}$, respectively, were calculated by combining the indirect and direct Ekman volume transport estimates with $\Theta$ and $S_{\mathrm{A}}$ from different sources. Note that in order to calculate the Ekman fluxes in the context of mass conservation (Montgomery, 1974), it has to be assumed that the Ekman volume transport in the upper layer is balanced by an equal and opposite geostrophic return flow at depth. This is a reasonable assumption and has been routinely adopted in many inverse studies (Ganachaud and Wunsch, 2003). To account for this return flow, an averaged conservative temperature, $\bar{\Theta}$, and absolute salinity $\overline{S_{\mathrm{A}}}$ were subtracted from the in situ $\Theta$ and $S_{\mathrm{A}}$ at each section. $\bar{\Theta}$ and $\overline{S_{\mathrm{A}}}$ are the zonally and vertically $(0-5000 \mathrm{~m})$ averaged conservative temperature and absolute salinity, calculated from the annual climatology of the World Ocean Atlas 2013 v2 (Locarnini et al., 2013; Zweng et al., 2013) at each section. In the following, the calculation details of the Ekman heat flux and transport-weighed Ekman temperature are given; the calculation of the Ekman salt flux and transport-weighted Ekman salinity is an analogue.

\subsubsection{Direct methods}

By using the in situ $\Theta$ together with the ageostrophic velocity within the layer from the sea surface to the TTP (referred to as the TTP layer), the Ekman heat flux $H_{\mathrm{e}}$ was calculated (referred to as the direct TTP/profile).

$H_{\mathrm{e}}=\rho C_{p} \int_{x_{1}}^{x_{2}} \int_{-\mathrm{TTP}}^{0}(\Theta(x, z)-\bar{\Theta}) v_{\text {ageo }}(x, z) \mathrm{d} z \mathrm{~d} x$,

where $C_{p}$ is the specific heat capacity of sea water at constant pressure, $\rho$ is the density of sea water, in this study we assumed a constant $C_{p}=4000 \mathrm{~J} \mathrm{~kg}^{-1} \mathrm{~K}^{-1}$ and a constant $\rho=1025 \mathrm{~kg} \mathrm{~m}^{-3}$, $v_{\text {ageo }}$ is the ageostrophic velocity, $\Theta$ is the in situ conservative temperature. $\bar{\Theta}$ is the mean conservative temperature at the corresponding section.

It is useful to consider the Ekman heat flux as the product of the Ekman volume transport, $M^{y}$, and the transportweighted temperature, $\Theta_{\mathrm{E}}$. The transport-weighted temperature then can be calculated as follows:

$\Theta_{\mathrm{E}}=\frac{\int_{x_{1}}^{x_{2}} \int_{-\mathrm{TTP}}^{0} \Theta(x, z) v_{\text {ageo }}(x, z) \mathrm{d} z \mathrm{~d} x}{M_{\text {direct }}^{y}}$.

As a comparison to the direct TTP/profile method, the Ekman heat fluxes using only in situ SST from the CTD and uCTD were also calculated (referred to as the direct TTP/surface). This was done by replacing the in situ $\Theta(x, z)$ in Eqs. (3) and (4) with the in situ SST $\Theta(x, z=0)$.

The uncertainty of the direct Ekman heat and salt fluxes was estimated following Chereskin et al. (2002). Since the wind direction was predominantly uniform and westward, the uncertainty should mainly arise from the ageostrophic velocity that was opposite to the expected Ekman flow direction. Therefore, the uncertainty was calculated still using Eqs. (3) and (4), except that only southward or northward ageostrophic velocity was used in both the numerator and denominator for the $14.5^{\circ} \mathrm{N}$ or $11^{\circ} \mathrm{S}$ section, respectively.

\subsubsection{Indirect surface method}

Often Ekman heat and salt fluxes are estimated by combining the Ekman volume transport inferred from wind stress with the SST and sea surface salinity (SSS) from a climatology or satellite measurements (e.g. McCarthy et al., 2015). Here, 
we calculated the heat flux using in situ wind and in situ SST data (referred to as the indirect surface) to compare with the direct estimates. Additionally, annual Ekman heat and salt fluxes (referred to as the indirect annual) were calculated using an annual average of the monthly NCEP/NCAR reanalysis wind stress data between 1991 and 2013 and the annual average of SST and SSS from the Roemmich and Gilson (2009) monthly Argo climatology (hereafter RG climatology). Following Levitus (1987), the Ekman heat flux for the indirect surface method was calculated as

$H_{\mathrm{e}}=C_{p} \int(\Theta(x, z=0)-\bar{\Theta}) \frac{\tau_{x}}{f} \mathrm{~d} x$,

where $\tau_{x}$ is the in situ wind stress in the tangential direction of the cruise track, $f$ is the Coriolis parameter, and $\Theta(x, z=$ 0 ) is the in situ SST. The transport-weighted temperature was calculated as follows:

$\Theta_{\mathrm{E}}=\frac{\int \Theta(x, z=0) \frac{\tau_{x}}{\rho f} \mathrm{~d} x}{M_{\text {indirect }}^{y}}$.

The indirect annual method is an analogue to the indirect surface method, except that the Ekman volume transport and SST were derived from the NCEP/NCAR reanalysis wind stress and RG climatology, respectively.

\subsubsection{Indirect TTP method}

Wijffels et al. (1996) assumed a linear Ekman velocity profile between the surface and TTP and calculated the Ekman heat and salt fluxes using climatological wind stress data, combined with the in situ temperature and salinity. Here we followed their method and used the in situ $\Theta, S_{\mathrm{A}}$, and wind to calculate the Ekman heat and salt fluxes (referred to as the indirect TTP) as a counterpart to the direct TTP method.

$$
\begin{aligned}
& H_{\mathrm{e}} \\
& =C_{p} \int\left[\frac{2}{3} \Theta(x, z=0)+\frac{1}{3} \Theta(x, z=\mathrm{TTP})-\bar{\Theta}\right] \frac{\tau_{x}}{f} \mathrm{~d} x,
\end{aligned}
$$

where $\Theta(x, z=$ TTP $)$ is the in situ conservative temperature at TTP depth from the CTD/uCTD. The transport-weighted temperature was calculated as follows:

$\Theta_{\mathrm{E}}=\frac{\int\left[\frac{2}{3} \Theta(x, z=0)+\frac{1}{3} \Theta(x, z=\mathrm{TTP})\right] \frac{\tau_{x}}{\rho f} \mathrm{~d} x}{M_{\text {indirect }}^{y}}$.

\section{Results and discussion}

\subsection{Upper layer hydrography at $14.5^{\circ} \mathrm{N}$ and $11^{\circ} \mathrm{S}$}

Along both sections (Fig. 2a, b) the typical upward tilting of isotherms towards the east, as a result of the subtropical gyre circulation, can be seen. Along the nominal $14.5^{\circ} \mathrm{N}$ section, the water in the upper $50 \mathrm{~m}$, compared to that at $11^{\circ} \mathrm{S}$, was relatively warm and fresh, with an averaged $\Theta$ and $S_{\mathrm{A}}$ of about $26.03^{\circ} \mathrm{C}$ and $36.15 \mathrm{~g} \mathrm{~kg}^{-1}$, respectively. The minimum $S_{\mathrm{A}}$ core near the western boundary probably originates from the freshwater runoff from the Amazon River (Fig. 2c). Together with the warm temperature, it forms the lightest water observed along the section (Fig. 2e). A subsurface salinity maximum layer of Subtropical Underwater (STUW) is centred at $100 \mathrm{~m}$ depth with $S_{\mathrm{A}}$ greater than $37.2 \mathrm{~g} \mathrm{~kg}^{-1}$. STUW is formed in the subtropical Atlantic with a SSS maximum due to excessive evaporation, and is subducted equatorward (Talley et al., 2011). The upward tilt of the isopycnals from west to east is suggestive of a net southward geostrophic transport when excluding the western boundary, where sharp deepening of the isopycnals implies a northward, intensified boundary current (Fig. 2g). At $11^{\circ} \mathrm{S}$, the surface water was cooler and more saline than that at $14.5^{\circ} \mathrm{N}$, with an averaged $\Theta$ and $S_{\mathrm{A}}$ of about $24.52^{\circ} \mathrm{C}$ and $36.69 \mathrm{~g} \mathrm{~kg}^{-1}$. The STUW with maximum salinity larger than $37.3 \mathrm{~g} \mathrm{~kg}^{-1}$ was centred at about $100 \mathrm{~m}$, but was even saltier than that at $14.5^{\circ} \mathrm{N}$. Likewise, a net northward geostrophic flow can be anticipated from the displacement of the isopycnals. At the western boundary, the North Brazil Undercurrent (NBUC) is characterized by a narrow and strong northward velocity band west of $35^{\circ} \mathrm{W}$ (Schott et al., 2005) (Fig. 2h). In the hydrographic data $\Theta / S_{\mathrm{A}}$ variability is seen at both sections that are associated with mesoscale eddies. For instance, at $14.5^{\circ} \mathrm{N} / 25^{\circ} \mathrm{W}$ and $11^{\circ} \mathrm{S} / 7^{\circ} \mathrm{E}$, cyclonic and anticyclonic eddies were characterized by the upward peak of the isotherms, and were clearly visible from the geostrophic velocity sections (Fig. 2g, h).

The daily $\Theta$ and $S_{\mathrm{A}}$ data of the GECCO2 synthesis were extracted from the model grid to the nearest time and position of the ship measurement. In general, GECCO2 daily data reproduced the observed hydrographic structure very well (not shown). The upward tilt of the isopycnals from the west to the east and the subsurface salinity maximum with $S_{\mathrm{A}}$ larger than $37.2 \mathrm{~g} \mathrm{~kg}^{-1}$ were clearly captured by GECCO2. However, the most obvious difference was at the western boundary of $11^{\circ} \mathrm{S}$, where the surface salinity was not as high as the observed values, and the isopycnals were not tilting in the same direction, indicating that the shallow western boundary current in the GECCO2 flowed in the opposite direction compared to the observation at $11^{\circ} \mathrm{S}$. But we expect that this difference should not impact the ageostrophic velocity calculation, since the geostrophic velocity must be removed from the total velocity. 

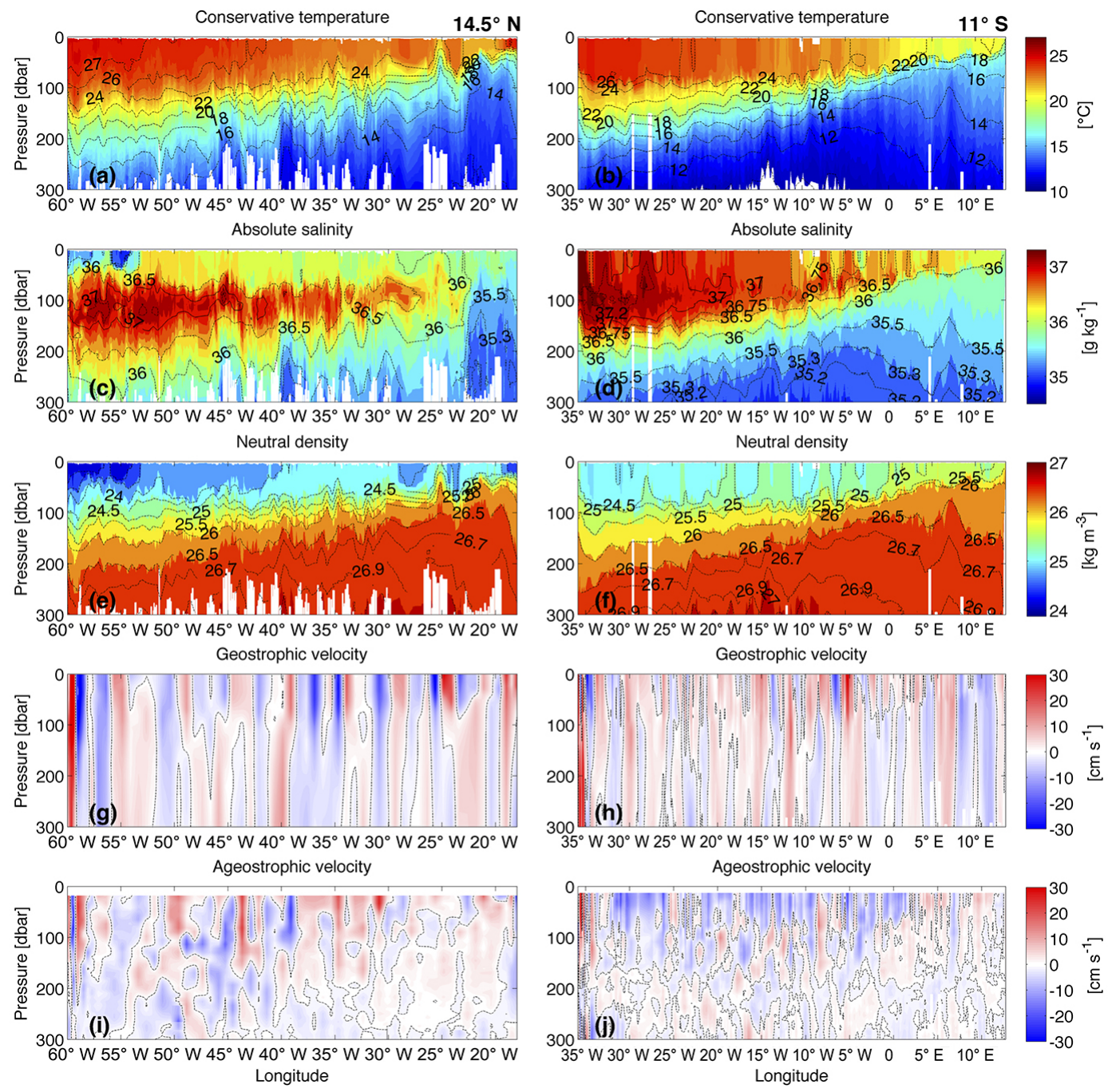

Figure 2. Vertical sections of conservative temperature in ${ }^{\circ} \mathrm{C}(\mathbf{a}, \mathbf{b})$, absolute salinity in $\mathrm{g} \mathrm{kg}^{-1}(\mathbf{c}, \mathbf{d})$, neutral density in $\mathrm{kg} \mathrm{m}^{-3}$ (e, f), geostrophic velocity in $\mathrm{cms}^{-1}(\mathbf{g}, \mathbf{h})$, and ageostrophic velocity in $\mathrm{cm} \mathrm{s}^{-1}(\mathbf{i}, \mathbf{j})$ at $14.5^{\circ} \mathrm{N}$ (left) and $11^{\circ} \mathrm{S}$ (right). All the available CTD and uCTD data were used to produce (a-f), and the contours were plotted with every fifth value for visual clarity. (g) and (i) were calculated using only CTD data, while (h) and (j) were calculated using CTD and uCTD data. The blanks were due to the shallow measurement depth of the uCTD.

\subsection{Vertical structure of the ageostrophic flow}

Although northward (southward) ageostrophic velocity at $14.5^{\circ} \mathrm{N}\left(11^{\circ} \mathrm{S}\right)$ dominates the upper $50-70 \mathrm{~m}$ (Fig. $2 \mathrm{i}, \mathrm{j}$ ), as expected from the persistent westward trade winds, the appearance of southward (northward) velocity at $14.5^{\circ} \mathrm{N}$ $\left(11^{\circ} \mathrm{S}\right)$ in the upper $50-70 \mathrm{~m}$ and below indicates the existence of non-Ekman ageostrophic components in the water column. This will be discussed in detail below. The sectionaveraged ageostrophic velocity based on CTD data at $14.5^{\circ} \mathrm{N}$ shows a relatively complicated vertical structure with multiple maxima and minima (Fig. 3a). It has a northward maximum velocity of $3.5 \mathrm{~cm} \mathrm{~s}^{-1}$ near the surface, and decreases to about $0.3 \mathrm{~cm} \mathrm{~s}^{-1}$ at about $60 \mathrm{~m}$, followed by a minor peak at about $80 \mathrm{~m}$ before approaching 0 at $100 \mathrm{~m}$. Another peak of $1 \mathrm{~cm} \mathrm{~s}^{-1}$ appears at about $150 \mathrm{~m}$, and below $180 \mathrm{~m}$ the velocity changes direction. When the ageostrophic velocity is calculated based on the uCTD data, it has a very consistent structure and strength compared to the CTD-based ageostrophic velocity (Fig. 3a). This is meaningful information as the hydrographic data at $11^{\circ} \mathrm{S}$ consist primarily of uCTD data. The good agreement between the CTD and uCTD data analysis at $14.5^{\circ} \mathrm{N}$ justifies the use of either one or the other. At $11^{\circ} \mathrm{S}$, the ageostrophic velocity shows a nearsurface southward maximum of $4.3 \mathrm{~cm} \mathrm{~s}^{-1}$, decreases almost linearly in the upper $70 \mathrm{~m}$, and gradually approaches 0 at about $100 \mathrm{~m}$ (Fig. 3b). In contrast to the northern section the vertical variations of the ageostrophic velocity profile below $100 \mathrm{~m}$ are very small. 

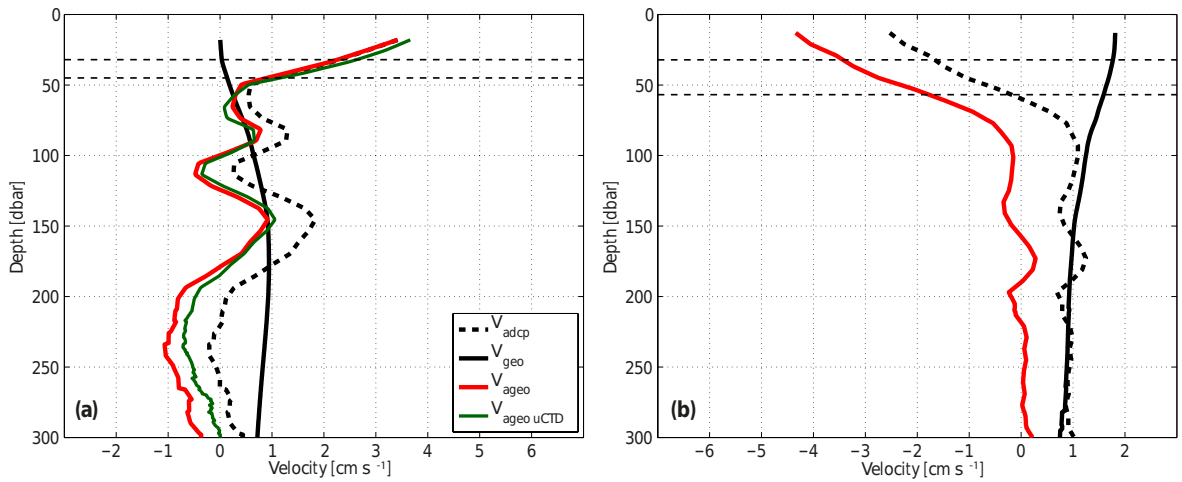

Figure 3. Section-averaged cross-track velocity profiles at (a) $14.5^{\circ} \mathrm{N}$ and (b) $11^{\circ} \mathrm{S}$. In (a), the solid red curve and the solid black curve are the ageostrophic and geostrophic velocity calculated from the CTD data, respectively. The dark green curve is the ageostrophic velocity profile based only on the uCTD data. In (b), the solid red curve and solid black curve are the ageostrophic and geostrophic velocity calculated from the combination of the CTD/uCTD data, respectively. The dashed black curve is the ADCP velocity. The upper horizontal dashed line denotes the basin-wide averaged MLD and the lower one denotes the basin-wide averaged TTP depth.
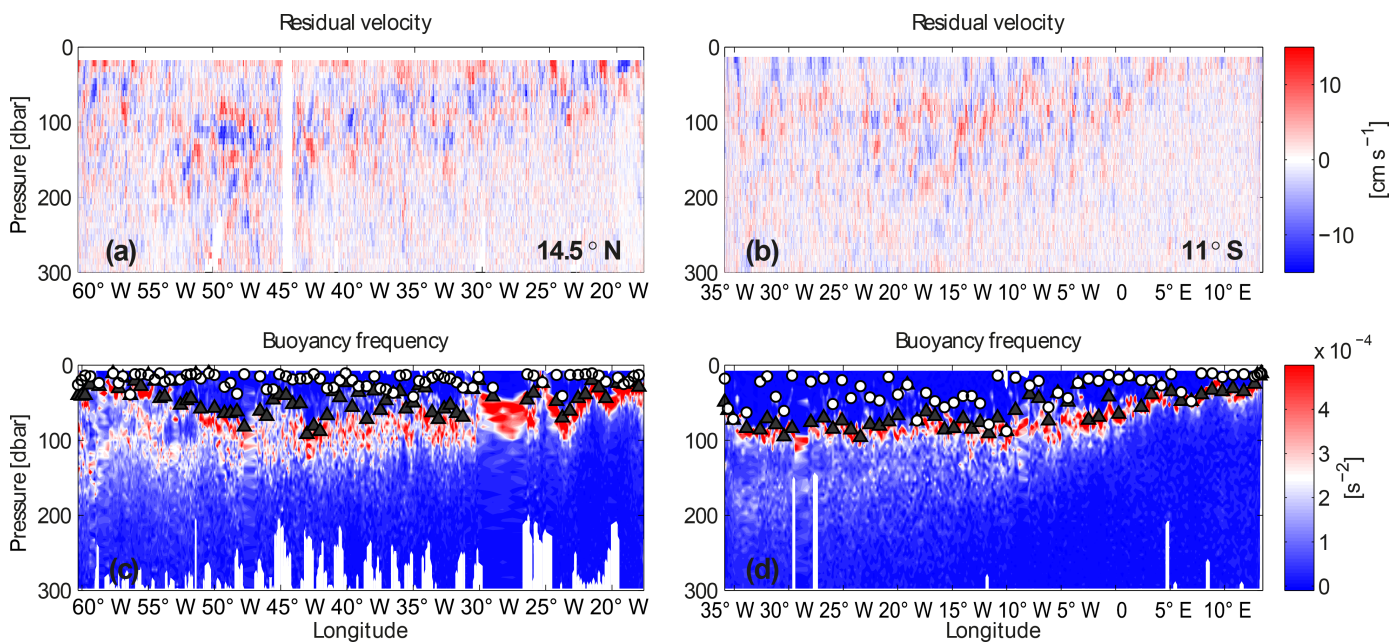

Figure 4. Vertical sections of residual meridional velocity in $\mathrm{cm} \mathrm{s}^{-1}$ at (a) $14.5^{\circ} \mathrm{N}$ and (b) $11^{\circ} \mathrm{S}$ and of buoyancy frequency calculated from $\mathrm{uCTD} / \mathrm{CTD}$ at $(\mathbf{c}) 14.5^{\circ} \mathrm{N}$ and $(\mathbf{d}) 11^{\circ} \mathrm{S}$. Northward velocity in $(\mathbf{a}, \mathbf{b})$ is shaded in red, southward in blue. The residual velocity is calculated by subtracting an $80 \mathrm{~m}$ boxcar filtered profile from the original ADCP profile. The white circles in (c, d) denote the MLD; the black triangles denote the TTP (see text for details). The MLD and TTP plotted here are subsampled for visual clarity. Note that no uCTD measurements were conducted between 30 and $25^{\circ} \mathrm{W}$ at $14.5^{\circ} \mathrm{N}$.

Assuming that the Ekman balance would hold true along the analysed sections, the ageostrophic velocity would decrease undisturbed from its surface maximum to about 0 at a certain depth (Ekman depth, $D_{\mathrm{E}}$ ). However, the observed wave-like structure at $14.5^{\circ} \mathrm{N}$ indicates that other processes must play a role in setting the section mean ageostrophic flow field. To identify this wave-like structure, we tried to separate the non-Ekman ageostrophic flow from the other components by using the ADCP velocity. A residual velocity was calculated by subtracting an $80 \mathrm{~m}$ boxcar filtered velocity profile from the original ADCP meridional velocity (Fig. 4a, b). The $80 \mathrm{~m}$ filter window was determined based on the vertical length scale of the wave-like structure in the sectionaveraged ageostrophic velocity profile by visual inspection.
At $14.5^{\circ} \mathrm{N}$, vertically alternating structures with wavelengths of $60-80 \mathrm{~m}$ are clearly visible, are coherent and persistent throughout the section, and are most pronounced between 52 and $46^{\circ} \mathrm{W}$ (Fig. 4a). At $11^{\circ} \mathrm{S}$, similar signals are visible for most of the section, but are not as strong as at $14.5^{\circ} \mathrm{N}$ (Fig. 4b).

Zonally averaging the residual velocity results in a velocity profile with a vertically alternating structure similar to that in the section-averaged ageostrophic velocity in both strength and structure, indicating that the vertical variation in the ageostrophic velocity mainly arises from the presence of high-order baroclinic waves. Figure $4 \mathrm{c}$ and $\mathrm{d}$ show the buoyancy frequency $\left(N^{2}\right)$ for the two sections, respectively. It appears that the wave-like signals occur mainly in the strongly 
stratified layer (pycnocline) marked by high $N^{2}$ values. $N^{2}$ is calculated as follows:

$N^{2}=\frac{g}{\rho_{0}} \frac{\partial \rho(z)}{\partial z}$,

where $g$ is the gravitational acceleration, $\rho_{0}=1025 \mathrm{~kg} \mathrm{~m}^{-3}$ is the reference density, and $\rho(z)$ is the in situ potential density as a function of depth, $z . \rho(z)$ was calculated by using a combination of CTD and UCTD profile data with a re-gridded vertical resolution of $5 \mathrm{~m}$ at both sections.

Chereskin and Roemmich (1991) also observed energetic, circularly polarized, relative currents of large horizontal coherence below the base of the mixed layer at $11^{\circ} \mathrm{N}$ in the Atlantic. They described the signal as the propagation of nearinertial internal waves and argued that the presence of a nearinertial peak in internal wave spectra, together with continuously varying wind forcing, would guarantee the appearance of these waves. Using satellite-based wind stress data, we examined the changes in wind stress at the measurement points within the last 2 weeks before the ship arrived at the measurement points. Although the wind stress strongly changed along the whole section, it is still not indicative why the wave signal is strongest between 52 and $46^{\circ} \mathrm{W}$ at $14.5^{\circ} \mathrm{N}$. It is tempting to believe that these waves are near-inertial internal waves. However, due to the fact that the ship moved nearly constantly except when it was on station, it is extremely difficult to identify what exactly these signals are. More sophisticated methods may be applied to analyse the wave-like signal; for instance, Smyth et al. (2015) took the Doppler shift in the shipboard current measurement into account, and translated observed Yanai wave properties into the reference frame of the mean zonal flow. But this is obviously beyond the scope of this work.

\subsection{Ekman transport}

\subsubsection{Indirect method}

According to Eq. (1), the Ekman transport can be calculated from the wind stress data (referred to as the indirect method) by integrating the left-hand side of Eq. (1) zonally. The in situ wind stress data and a satellite-based wind stress product from CMEMS were used. The satellite wind stress data were extracted from the original grid to the nearest time and nearest position of the ship navigation. Both in situ and satellite wind stress were projected to the tangential direction of the cruise track, so that the cross-sectional Ekman transport at each grid point was calculated. Note that both sections were occupied nominally zonally; therefore, we will refer to crosssectional Ekman transport as meridional Ekman transport for simplicity hereafter.

Overall, the satellite wind stress agrees well with the ship wind stress (Fig. 5) except in the region between 40 and $30^{\circ} \mathrm{W}$ at $14.5^{\circ} \mathrm{N}$, where the zonal ship wind stress is larger than the zonal satellite wind stress, and at $11^{\circ} \mathrm{S}$ the ship wind stress is generally smaller than the satellite wind stress. Since the $10 \mathrm{~m}$ wind speeds from the ship and satellite are very close to each other at both sections (not shown), the difference in the wind stress may be due to the use of a different drag coefficient formulation (COARE 3 for the CMEMS wind product; Large and Yeager, 2004, for ship wind stress). In comparison to the NCAR/NCEP monthly zonal wind stress, the weaker ship wind stress in the western half of the $14.5^{\circ} \mathrm{N}$ section indicates that the cruise started with anomalously weak winds, while at $11^{\circ} \mathrm{S}$ the observed wind stress (both ship and satellite observation) was consistent with the monthly mean wind stress. It is also reported that differences in the different wind stress data may also arise from the unresolved local effect by the satellites and NCEP data (Mason et al., 2011; Pérez-Hernández et al., 2015). For instance, near the Canary Islands, the NCEP monthly data do not resolve the Von Karman structure caused by the interaction of wind with the islands due to its low resolution.

As expected, at $14.5^{\circ} \mathrm{N}$, the indirect estimate of the Ekman transport from the in situ wind stress is $6.7 \pm 3.5 \mathrm{~Sv}$, only $0.4 \mathrm{~Sv}$ larger than that from the satellite wind stress. Using the monthly mean wind stress from NCEP/NCAR during the M96/M97 cruise month (May 2013), the total transport is $8.8 \pm 1.4 \mathrm{~Sv}$. The difference between the monthly wind estimate and in situ wind estimate is mainly due to the anomalously weak wind when the cruise started from the western boundary (Fig. 5a). At $11^{\circ} \mathrm{S}$, the indirect Ekman transport from the in situ wind stress is $13.6 \pm 3.3 \mathrm{~Sv}$, while the transport from the satellite wind stress is $2.0 \mathrm{~Sv}$ higher, due to the higher value of the satellite wind stress (Fig. 5b). The NCEP/NCAR monthly wind stress in July 2013 returns a transport of $15.1 \pm 1.9 \mathrm{~Sv}$. The errors shown with the indirect ship wind estimates are given by the standard deviation of the long-term Ekman transport calculated using $6 \mathrm{~h}$ NCEP/CFSR wind stress between the years 2000 and 2011 at the two latitudes. The errors of the monthly estimates are given by the standard deviation of the monthly mean Ekman transport in May (July) between 1979 and 2013 at $14.5^{\circ} \mathrm{N}\left(11^{\circ} \mathrm{S}\right)$ calculated from the NCEP/NCAR monthly wind stress. Another source of uncertainty may arise from the wind stress calculation using different bulk formulas, which could lead to an uncertainty as large as $20 \%$ (Large and Pond, 1981). This may explain the difference in the indirect estimates between using the in situ wind stress and the satellite wind stress at $11^{\circ} \mathrm{S}$.

\subsubsection{Direct method}

The direct meridional Ekman transport is derived from vertically integrating the ageostrophic velocity profiles (Eq. 1, right-hand side). As already mentioned, one critical assumption is the integration depth $\left(D_{\mathrm{E}}\right)$. Applying the TTP as an estimate of $D_{\mathrm{E}}$, the total Ekman transport at $14.5^{\circ} \mathrm{N}$ based on CTD data is $6.2 \pm 2.3 \mathrm{~Sv}$, while applying a uniform depth of $50 \mathrm{~m}$ results in an alternative estimate of 

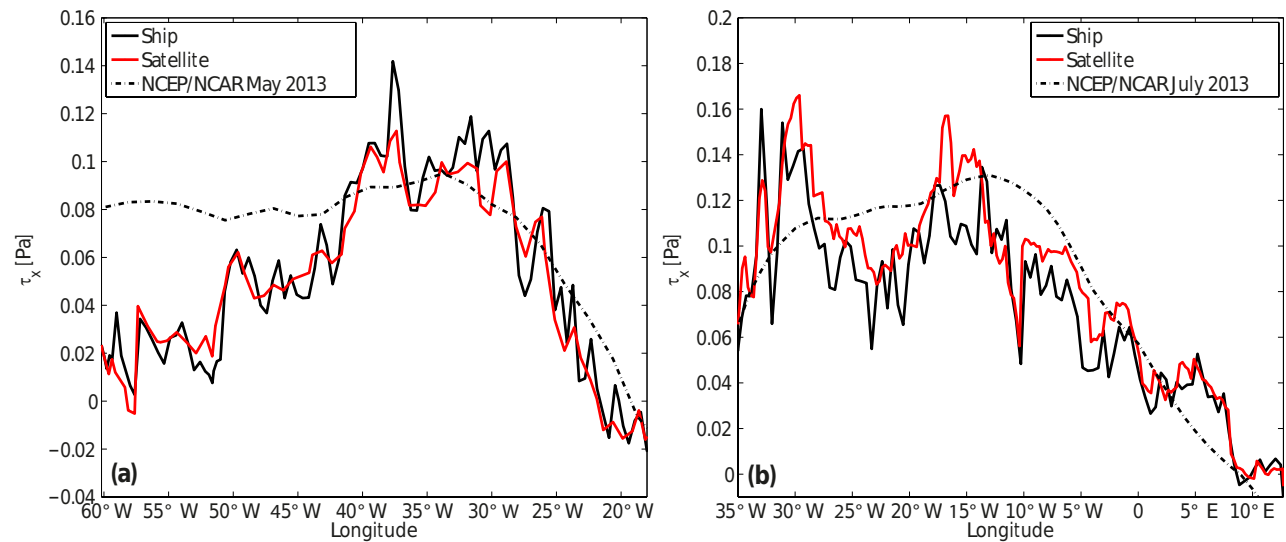

Figure 5. Zonal wind stress along (a) $14.5^{\circ} \mathrm{N}$ and (b) $11^{\circ} \mathrm{S}$. Ship wind stress (black line) was binned in a $50 \mathrm{~km}$ interval. The satellite wind stress data (red) were extracted to the nearest ship time and position. The NCEP reanalysis monthly zonal wind stress (black dashed line) at the same latitude in the cruise month is also plotted.

$6.5 \pm 1.9 \mathrm{~Sv}$, and applying the local MLD results in a transport of $5.1 \pm 1.4 \mathrm{~Sv}$. When integrating the ageostrophic velocity calculated from the uCTD data to the TTP, the Ekman transport is $6.6 \pm 2.3 \mathrm{~Sv}$. At $11^{\circ} \mathrm{S}$, the direct estimate by applying the TTP, a uniform depth of $80 \mathrm{~m}$, and the MLD is $-11.7 \pm 2.1 \mathrm{~Sv},-12.0 \pm 2.4 \mathrm{~Sv}$, and $-8.0 \pm 1.4 \mathrm{~Sv}$, respectively ("-" denotes southward transport). The errors given with the transport estimates were calculated by considering the aliasing effect of the inertial waves during the cruises following Chereskin and Roemmich (1991) as described in Sect. 3.3.

Because the shallowest valid bin depth of the ADCP measurement was $18 \mathrm{~m}(13 \mathrm{~m})$ at $14.5^{\circ} \mathrm{N}\left(11^{\circ} \mathrm{S}\right)$, the ageostrophic velocity was extrapolated linearly to the surface using the value of the first two bins. Note that we did not assume a surface maximum of the ageostrophic velocity everywhere, since for individual profiles the ageostrophic velocity at the first bin depth may be smaller than that at the second bin, which would result in a smaller surface ageostrophic velocity. In previous studies (Chereskin and Roemmich, 1991; Wijffels et al., 1994), the velocity above the first ADCP bin was assumed to equal the value at the first bin. Using this assumption would reduce Ekman transport at $14.5^{\circ} \mathrm{N}$ by $0.56 \mathrm{~Sv}$ ( $9 \%$ of total northward transport), and at $11^{\circ} \mathrm{S}$ by $0.14 \mathrm{~Sv}$ ( $1 \%$ of total southward transport). According to the classical Ekman theory, the surface Ekman velocity $\left(V_{0}\right)$ is $45^{\circ}$ to the right (left) of the wind blowing direction in the Northern (Southern) Hemisphere and can be derived from the total wind stress (see the definition of $V_{0}$ in Eq. 1). As a comparison to the linear extrapolation above the first ADCP bin, we also calculated the meridional Ekman velocity at the surface using the total in situ wind stress and a constant $A_{\mathrm{v}}$ of $0.02 \mathrm{~m}^{2} \mathrm{~s}^{-1}$. Then the meridional ageostrophic velocity above the first ADCP bin was linearly interpolated using the value at the first bin and the surface meridional Ekman velocity predicted from the in situ wind stress. The resulting
Ekman transport is $1.2 \mathrm{~Sv}(0.7 \mathrm{~Sv})$ smaller than that using a linear extrapolation method at $14.5^{\circ} \mathrm{N}\left(11^{\circ} \mathrm{S}\right)$. Note that we chose a linear extrapolation method, because it resulted in a better agreement between the indirect and direct estimates, but it may overestimate the total ageostrophic transport.

A question that follows is whether the ageostrophic flow in the mixed layer has shear or is constant with depth referred to a slab-like shape. Given the large variation of the MLD throughout the sections, basin-wide averages are inconclusive. Chereskin and Roemmich (1991) found shear structure in the mixed layer at $11^{\circ} \mathrm{N}$ in the Atlantic, while Wijffels et al. (1994) reported a slab-like shape at $10^{\circ} \mathrm{N}$ in the $\mathrm{Pa}-$ cific, and attributed the shear structure found by Chereskin and Roemmich (1991) to an improper definition of the MLD. Following their method, the depth was normalized by the local MLD before averaging the ageostrophic velocity across the basin (Fig. 6). At $14.5^{\circ} \mathrm{N}$, for a slab-like ageostrophic structure, Fig. 6 would show a nearly constant profile from the surface to about the MLD. Instead, it shows strong shear above the MLD. Such strong shear is insensitive to the definition of the MLD. For example, choosing a density threshold of $0.005 \mathrm{~kg} \mathrm{~m}^{-3}$, the shear still exists below 0.4 MLD. At $11^{\circ} \mathrm{S}$, no slab-like structure in the ageostrophic velocity was found, either. The constant value above 0.4 MLD is a consequence of using a constant velocity above $18 \mathrm{~m}$, the shallowest ADCP bin. Therefore, we would conclude that ageostrophic shear exists within the mixed layer in our cases, as expected from the classical Ekman theory.

The cumulative Ekman transport from the western to the eastern boundary shows an overall match between the direct and indirect methods (Fig. 7a, b). At $14.5^{\circ} \mathrm{N}$, the in situ wind was relatively weak at the beginning and the end of the section. Correspondingly, the increment in transport within these two segments was moderate, while in the central part of the section, where the wind was strong, the rapid accumulation of Ekman transport is directly visible in both indi- 


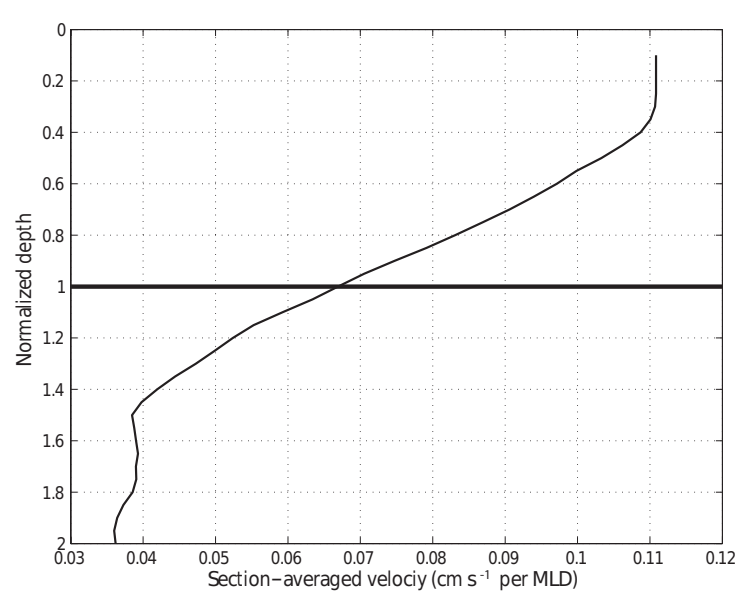

Figure 6. Section-averaged ageostrophic velocity at $14.5^{\circ} \mathrm{N}$, normalized in depth by the local MLD. Velocity above $18 \mathrm{~m}$ is set equal to the velocity at $18 \mathrm{~m}$. MLD is defined as the depth where the density is $0.01 \mathrm{~kg} \mathrm{~m}^{-3}$ different from the value at $10 \mathrm{~m}$.

rect and direct estimates. The direct estimates using TTP and $50 \mathrm{~m}$ depth are very close to the in situ wind estimates. The estimate using $50 \mathrm{~m}$ depth tends to overestimate the transport close to both ends of the section. Applying the MLD as integration depth tends to underestimate the total transport by about $1.5 \mathrm{~Sv}$, compared to the ship wind estimate. This is mainly because it fails to capture the increase between 30 and $25^{\circ} \mathrm{W}$. Note that the uCTD-based direct estimate is consistent with the CTD-based estimates, though it overestimates the transport in the middle of the section; the total transport as well as the transport structure are similar. This may be a result of the higher spatial resolution of the uCTD measurement, which captures more details in the horizontal features introduced by the wind.

At $11^{\circ} \mathrm{S}$, the wind was strong in the western half of the basin and gradually weakened in the eastern half towards the eastern boundary. Correspondingly, the Ekman transport accumulates rapidly to about $12 \mathrm{~Sv}$ at $0^{\circ} \mathrm{E}$, east of which the increment is very small for both direct and indirect estimates. Among the direct estimates, integrating the ageostrophic velocity to $80 \mathrm{~m}$ and TTP returns nearly identical transport in the western half of the section; the difference in the eastern half mainly reflects the shallower TTP towards the eastern boundary, while using the MLD for the integration underestimates the Ekman transport from the very beginning. Note that at both sections, the direct estimate using MLD is about one-fourth smaller than that using TTP depth. This agrees with the findings at $10^{\circ} \mathrm{N}$ in the Pacific by Wijffels et al. (1994), who reported that the Ekman flow within the mixed layer accounted for about two-thirds of the total Ekman transport, and the in situ wind predicted the Ekman transport down to the TTP. Recalling the definition of $D_{\mathrm{E}}$ in Eq. (1), the vertical eddy viscosity $A_{\mathrm{v}}$ can be estimated by using TTP as a representative of $D_{\mathrm{E}}$. At $14.5^{\circ} \mathrm{N}$, the mean $A_{\mathrm{v}}$ is $0.038 \mathrm{~m}^{2} \mathrm{~s}^{-1}$, and at $11^{\circ} \mathrm{S}$, the mean $A_{\mathrm{v}}$ is $0.045 \mathrm{~m}^{2} \mathrm{~s}^{-1}$. These results fall in the range of previous estimates of $A_{\mathrm{v}}$, which vary by more than 1 order of magnitude (Price et al., 1987; Chereskin, 1995; Lenn and Chereskin, 2009).

\subsection{Ekman transport from GECCO2}

The daily data of the GECCO2 synthesis (2008-2014) allowed us to estimate the model Ekman transport, inspect the vertical structure of the ageostrophic velocity in the model, and compare these results with the observations for the corresponding cruise time periods. The daily data were first extracted from the model grid to the nearest ship time and position. The Ekman transport in GECCO2 was calculated in a similar manner to the direct method used for the observational data. An ageostrophic velocity was calculated as the difference between the geostrophic velocity and total velocity with a reference depth of $200 \mathrm{~m}$. The geostrophic velocity was computed from the temperature and salinity of GECCO2. The direct estimate of the meridional Ekman transport in GECCO2 was obtained by integrating the meridional ageostrophic velocity vertically and zonally.

The section-averaged ageostrophic velocity at both sections shows a near-surface maximum at about $15 \mathrm{~m}$, and then decreases sharply to 0 at about $50 \mathrm{~m}$; the flow is purely geostrophic below $60 \mathrm{~m}$ (not shown). This vertical distribution of ageostrophic velocity indicates that the wind-driven Ekman component is the predominant contributor to the ageostrophic velocity in the GECCO2 model, and that nearly all the wind energy is utilized for the Ekman transport and confined to the upper $50 \mathrm{~m}$ at both sections. The total transport by integrating the ageostrophic velocity to $50 \mathrm{~m}$ is $7.6 \mathrm{~Sv}$ at $14.5^{\circ} \mathrm{N}$ and $12.0 \mathrm{~Sv}$ at $11^{\circ} \mathrm{S}$, respectively (Fig. 7), which is close to the indirect Ekman transport estimates based on GECCO2 daily wind stress of 7.4 and $13.4 \mathrm{~Sv}$, respectively.

This result agrees very well with the observed direct Ekman transport, which is likely due to the fact that GECCO2 daily wind stress has a similar magnitude to the in situ wind stress. The observed ageostrophic cumulative transport shows strong mesoscale fluctuations throughout the sections, which are characterized by the presence of northward and southward ageostrophic velocity even though the in situ wind is persistently westward, while the GECCO2 ageostrophic transport accumulates smoothly (Fig. 7).

\subsection{Ekman heat and salt fluxes}

The Ekman volume, heat, and salt fluxes calculated using different methods are summarized in Table 1. In the previous sections, we have shown that the TTP is a reasonable assumption for the depth of $D_{\mathrm{E}}$ for both sections. Hence, the direct TTP/profile method should give us the best estimate of the heat and salt fluxes. It is clear that the differences in Ekman volume transports dominate the differences in the resulting Ekman heat and salt fluxes. The higher Ekman volume 

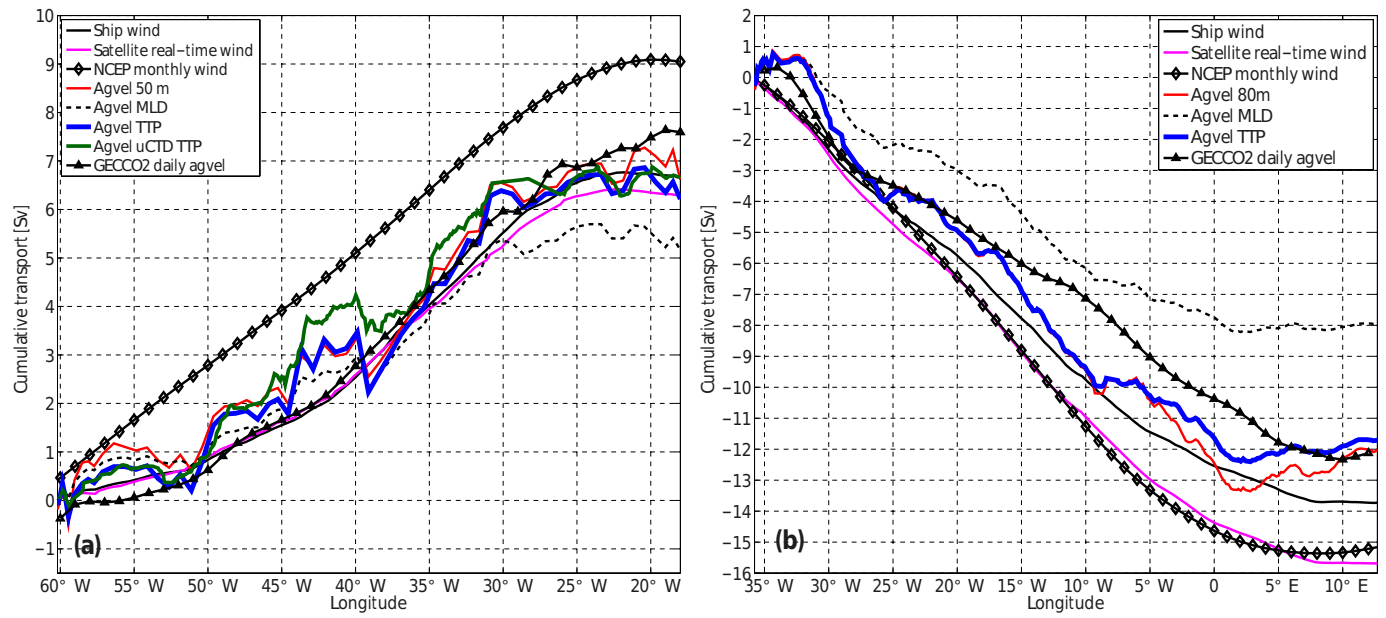

Figure 7. Cumulative meridional Ekman transport from the western to the eastern coast (a) at $14.5^{\circ} \mathrm{N}$ and (b) at $11^{\circ} \mathrm{S}$. For both sections, the black solid curve marks the indirect Ekman transport estimate from the in situ wind stress; the magenta solid curve denotes that from the satellite wind stress; and the black diamond line denotes that from the NCEP/NCAR monthly wind stress. The solid blue curve denotes the direct estimate by integrating the ageostrophic velocity to the TTP, the red solid to a uniform depth $\left(50 \mathrm{~m}\right.$ at $14.5^{\circ} \mathrm{N}$ and $80 \mathrm{~m}$ at $\left.11^{\circ} \mathrm{S}\right)$, and the black dashed line to the MLD. The black triangle line represents the direct estimate based on the GECCO2 daily data. The dark green line in (a) represents the direct estimate integrated to the TTP based only on the uCTD data.

transport by the indirect methods leads to higher heat and salt fluxes compared to the direct methods at both sections. At $14.5^{\circ} \mathrm{N}$, the transport-weighted Ekman temperature from the direct TTP/surface method is $0.10^{\circ} \mathrm{C}$ higher than that from the direct TTP/profile method. This temperature difference corresponds to a change in the heat flux of only less than $1 \%$, which is very small compared to the uncertainty caused by the volume transport uncertainty. The indirect TTP method returns the Ekman temperature and salinity value very close to that of the direct TTP/profile method, indicating that the assumption of a linear Ekman velocity profile between the surface and the TTP depth may be reasonable. This could be potentially interesting, since this method is independent of the ageostrophic velocity.

At $11^{\circ} \mathrm{S}$, the difference between the direct TTP/profile and direct TTP/surface methods is negligible. The transportweighted Ekman temperature from the indirect TTP and surface methods is significantly smaller than that from the direct methods. This may be caused by a combined effect of stronger Ekman volume transport by the indirect method near the eastern boundary (Fig. 7) and the cooler water temperature due to coastal upwelling. In other words, the indirect calculation tends to give excessive weighting to the cooler water, which results in lower values in the transport-weighted Ekman temperature. Such a combined effect has a limited impact on the Ekman salinity.

The difference in the Ekman heat flux when using temperature at the surface or within the TTP layer is much smaller than that for the extreme case at the end of the summer monsoon in the Indian Ocean in September 1995 reported by Chereskin et al. (2002). The choice of Ekman temperature and salinity has a negligible effect on the resulting heat and salt fluxes across the sections studied here.

Note that at $14.5^{\circ} \mathrm{N}$ (except for the indirect annual method) the Ekman heat fluxes (0.41-0.44 PW) estimated using direct and indirect methods based on ageostrophic velocity and in situ wind are generally smaller compared with the estimates of 0.7-0.8 PW by Levitus (1987) or 0.6-0.8 PW by Sato and Polito (2005). As described above, both the direct and indirect methods in this study reflect the Ekman transport driven by the in situ wind, which is weak compared to the monthly wind, especially in the western basin (Fig. 5a). By using the annual mean wind stress from NCEP/NCAR reanalysis and SST from RG climatology, the Ekman heat flux is $0.58 \mathrm{PW}$, which is close to the estimates of Sato and Polito (2005). At $11^{\circ} \mathrm{S}$, the direct and indirect Ekman heat fluxes $(0.8-0.96 \mathrm{PW})$ are rather close to the estimate of $1.05 \mathrm{PW}$ by Levitus (1987) or within the range of values (0.7-1.0 PW) estimated by Sato and Polito (2005). Here, the Ekman volume transports estimated from in situ wind and from the annual averaged wind were similar.

It is worth noting that the Ekman salt flux presented in this study may not be representative of an annual or long-term mean Ekman salt flux, but it may provide insight into the sensitivity of the Ekman salt flux to changes in Ekman volume transport and Ekman-layer salinity. This might help in constraining salt conservation and resulting freshwater flux in studies of the meridional overturning circulation in the same region. 


\section{Summary}

The Ekman volume, heat, and salt transport across zonal sections at $14.5^{\circ} \mathrm{N}$ and $11^{\circ} \mathrm{S}$ in the Atlantic were calculated by using an ageostrophic-velocity-based method (direct method) and a wind-stress-based method (indirect method). A cross-sectional ageostrophic velocity was calculated at each section following Chereskin and Roemmich (1991) and Wijffels et al. (1994) by subtracting the geostrophic velocity from the cross-sectional component of the ADCP velocity. At both sections, underway-CTD profiles were used for the ageostrophic velocity calculation. A comparison between the results based on standard CTD and uCTD data at $14.5^{\circ} \mathrm{N}$ revealed a consistent transport estimate with a robust vertical ageostrophic velocity structure and horizontal distribution of the Ekman transport. This has established our confidence in performing a similar calculation for the $11^{\circ} \mathrm{S}$ section, along which primarily uCTD profiles were taken.

The section-averaged ageostrophic velocity at $14.5^{\circ} \mathrm{N}$ and $11^{\circ} \mathrm{S}$ has a near-surface northward and southward maximum of 3.5 and $4.3 \mathrm{~cm} \mathrm{~s}^{-1}$, and decreases below to reach about zero at 60 and $100 \mathrm{~m}$, respectively. This is an indication of the Ekman spiral, and is consistent with the findings of Chereskin and Roemmich (1991) at $11^{\circ} \mathrm{N}$ in the Atlantic, Wijffels et al. (1994) at $10^{\circ} \mathrm{N}$ in the Pacific, and Chereskin et al. (1997) at $8.5^{\circ} \mathrm{N}$ in the Indian Ocean. Near-inertial oscillations are regarded as a dominant source of ageostrophic noise, which is superimposed upon the Ekman flow, but zonal averaging or integration over several inertial periods should remove most of it. However, below the surface-intensified Ekman flow, the ageostrophic velocity along both sections shows wave-like structures of $50-80 \mathrm{~m}$ vertical scale with multiple maxima and minima. By applying a boxcar filter, these wave-like signals were separated from the crosssectional ADCP velocity (Fig. 4). The appearance of these structures is mainly below the TTP and coincides with the layer of maximum buoyancy frequency. They are characterized by vertically alternating horizontal velocities with large horizontal coherence. Chereskin and Roemmich (1991) also reported the presence of such waves within the main thermocline, which were coherent over large horizontal space scales. These are thought to be near-inertial internal waves.

The section-averaged ageostrophic velocity had its maximum at the depth of the first valid bin of the ADCP (13$18 \mathrm{~m}$ ), indicating that a shear existed within the ML, despite its homogeneous density. Chereskin and Roemmich (1991) examined this at $11^{\circ} \mathrm{N}$ in the Atlantic by zonally averaging a MLD-normalized ageostrophic velocity, and concluded that shear existed in the ML. However, Wijffels et al. (1994) applied the same technique and found a slab-like layer of ageostrophic velocity above the MLD at $10^{\circ} \mathrm{N}$ in the $\mathrm{Pa}-$ cific and attributed the discrepancy to a loose definition of the MLD by Chereskin and Roemmich (1991). Following their methods, we also examined whether there was shear in the ageostrophic velocity within the ML along the two sections.
It appears that at both sections, an ageostrophic shear existed in the ML, and this conclusion does not change if a more rigorous constraint on the MLD is used (Fig. 6).

The Ekman transport estimated by integrating the ageostrophic velocity zonally through the section and vertically to the local TTP depth is $6.2 \pm 2.3$ and $11.7 \pm 2.1 \mathrm{~Sv}$ at $14.5^{\circ} \mathrm{N}$ and $11^{\circ} \mathrm{S}$, respectively, which compares reasonably well to the estimates of $6.7 \pm 3.5$ and $13.6 \pm 3.3 \mathrm{~Sv}$ by using the in situ wind stress data. By using a fixed integration depth of $50 \mathrm{~m}$ at $14.5^{\circ} \mathrm{N}$ and $80 \mathrm{~m}$ at $11^{\circ} \mathrm{S}$, the ageostrophic Ekman transport is not significantly different from those calculated using the TTP depth, while using the MLD as the integration depth, the ageostrophic Ekman transport is about one-fourth smaller than using the TTP depth. This is an indication that the wind-driven flow penetrates beyond the ML to the TTP, and it is consistent with the findings of Wijffels et al. (1994), who reported that two-thirds of the wind-driven transport was within the ML and that the TTP is a reasonable choice for the integration depth of the Ekman flow. Note that above the first ADCP bin (13-18 m), the meridional ageostrophic velocity was linearly extrapolated using the values from the first two bins. However, when the surface meridional Ekman velocity is assumed equal to the velocity of the first measured ADCP bin (constant extrapolation), or extrapolated toward the theoretical Ekman solution for the surface velocity, the total ageostrophic transport would be up to $1.2 \mathrm{~Sv}$ smaller than the results shown above. Therefore, the linear extrapolation may to some extent overestimate the Ekman transport.

Between the two sections, the poleward Ekman transport divergence is $17.9 \mathrm{~Sv}$, and the equatorward geostrophic convergence in the TTP layer is $6.2 \mathrm{~Sv}$. This result agrees with the conclusion derived from theoretical consideration by Schott et al. (2004), who stated that the poleward Ekman divergence induced by the trade winds in both hemispheres is compensated for by an equatorward convergence due to the geostrophic flow in the upper layer, but the compensation is generally assumed not to be strong enough to reverse the Ekman divergence.

Note that the Ekman volume transport and the Ekman divergence estimated above were obtained by using data sampled during two Atlantic transects. The time series of Ekman transport calculated from the $6 \mathrm{~h}$ NCEP/CFSr wind stress from 2000 to 2011 shows a clear seasonal cycle and interannual variability at both latitudes. The transport strength reaches its maximum in the winter months of the respective hemisphere, and its minimum in the summer months of the respective hemisphere. The annual climatology with standard deviation from this time series is $7.9 \pm 3.5 \mathrm{~Sv}$ at $14.5^{\circ} \mathrm{N}$ and $-10.4 \pm 3.3 \mathrm{~Sv}$ at $11^{\circ} \mathrm{S}$. Our direct Ekman transport estimates agree well with the annual climatology. The uncertainties in the direct Ekman transport estimates are given by considering the aliasing effect of the near-inertial waves during the cruise. However, a larger uncertainty can be expected when the seasonal to interannual variability of the Ekman transport is taken into account. 
The cumulative Ekman transport shows a rapid increase in the middle of the section and very little changes in the last quarter near the eastern boundary at both latitudes. This is because the zonal trade winds are generally strong and persistent in the western and middle parts of the basin, while relatively weak and unstable in strength and direction near the eastern boundary. Similar horizontal characteristics of Ekman transport were also seen at $11^{\circ} \mathrm{N}$ and $6^{\circ} \mathrm{S}$ in the Atlantic (Chereskin and Roemmich, 1991; Garzoli and Molinari, 2001) and $10^{\circ} \mathrm{N}$ in the Pacific (Wijffels et al., 1994). The GECCO2 ocean synthesis daily data were also used to calculate the meridional Ekman transport at $14.5^{\circ} \mathrm{N}$ and $11^{\circ} \mathrm{S}$ in the Atlantic by using the direct approach, which agrees very well with the observed results in respect to horizontal transport structure throughout the basin and the total transport amount. This was mostly due to the fact that GECCO2 assimilates the observed wind, and with a daily temporal resolution, it is possible for GECCO2 to reproduce the strength of the in situ wind, hence the Ekman transport. This good agreement has lent us more confidence in using GECCO2 as a reference in further studies on the MOC at the same latitudes.

An Ekman layer temperature and salinity must be assigned when calculating the Ekman heat and salt fluxes. Our results suggest that using the SST and SSS for the meridional Ekman heat and salt flux calculation at the two sections is only marginally different from calculations using the temperature and salinity in the TTP layer. It is rather the uncertainty in the Ekman volume transport estimates that dominates the uncertainties in the Ekman heat and salt fluxes. This is in good agreement with the finding at $10^{\circ} \mathrm{N}$ in the Pacific by Wijffels et al. (1994), while in striking contrast to that at $11^{\circ} \mathrm{N}$ in the Atlantic by Chereskin and Roemmich (1991), who found the transport-weighted Ekman temperature is $1^{\circ} \mathrm{C}$ cooler than the surface value. The reason for such a contrast is not clear, but it is possible that in their case the TTP was much deeper than the MLD, especially in the western half of the basin.

Since Ekman volume, heat, and salt transport are significant upper layer components of the MOC with respect to the mass, heat, and freshwater conservation, further studies on the vertical and horizontal structures of the Ekman flow, as well as on the Ekman heat and salt fluxes, are expected to deepen our understanding and facilitate the studies on MOC strength and variability. This study would also provide some reference for the follow-up studies on the MOC at the same latitudes.

Data availability. The level-4 near-real-time wind stress product is available at http://marine.copernicus.eu/ (EU Copernicus, 2016). The NCEP/NCAR monthly wind stress data are available at http: //rda.ucar.edu/datasets/ds090.2/ (National Centers for Environmental Prediction et al., 1996). The NCEP/CFSR $6 \mathrm{~h}$ wind stress data are available at http://rda.ucar.edu/datasets/ds093.0/ (Saha et al., 2010). The Roemmich-Gilson monthly Argo climatology is available at http://sio-argo.ucsd.edu/RG_Climatology.html. The GECCO2 ocean synthesis is available at http://icdc.cen.uni-hamburg.de/1/ projekte/easy-init/easy-initocean.html\#c2231. The World Ocean Atlas temperature and salinity data are available at https:// www.nodc.noaa.gov/OC5/woa13/. The shipboard measurements during cruises M96, M97, and M98 are available through PANGEA at https://doi.pangaea.de/10.1594/PANGAEA.870516 (Fu et al., 2017).

Competing interests. The authors declare that they have no conflict of interest.

Acknowledgements. We thank Toste Tanhua for closing the M96 section towards the African coast during M97, as well as all the research teams and crews onboard R/V Meteor for their dedicated work during the three cruise legs. We thank Armin Köhl for providing the GECCO2 data and the information about the data. We also thank Richard Greatbatch for the comments on a previous version of the manuscript, and Gerd Krahmann for providing the Matlab codes for uCTD sensor calibration. The blended level-4 wind stress data were provided by the Copernicus Marine Environment Monitoring Service (CMEMS). This study is funded by the Deutsche Forschungsgemeinschaft as part of cooperative project FOR1740 and by the German Federal Ministry of Education and Research as part of cooperative projects RACE (03F0605B) and SACUS (03F0751A).

Edited by: David Stevens

Reviewed by: two anonymous referees

\section{References}

Alford, M. H.: Improved global maps and 54-year history of windwork on ocean inertial motions, Geophys. Res. Lett., 30, 1424, https://doi.org/10.1029/2002GL016614, 2003.

Chereskin, T. K.: Direct evidence for an Ekman balance in the California Current, J. Geophys. Res., 100, 18261-18269, https://doi.org/10.1029/95JC02182, 1995.

Chereskin, T. K. and Roemmich, D.: A Comparison of Measured and Wind-derived Ekman Transport at $11^{\circ} \mathrm{N}$ in the Atlantic Ocean, J. Phys. Oceanogr., 21, 869-878, 1991.

Chereskin, T. K., Wilson, W. D., Bryden, H. L., Ffield, A., and Morrison, J.: Observations of the Ekman balance at $8^{\circ} 30^{\prime} \mathrm{N}$ in the Arabian Sea during the 1995 southwest monsoon, Geophys. Res. Lett., 24, 2541, https://doi.org/10.1029/97GL01057, 1997.

Chereskin, T. K., Wilson, W. D., and Beal, L. M.: The Ekman temperature and salt fluxes at $8^{\circ} 30^{\prime} \mathrm{N}$ in the Arabian Sea during the 1995 southwest monsoon, Deep-Sea Res. Pt. II, 49, , 1211-1230, https://doi.org/10.1016/S0967-0645(01)00168-0, 2002.

Cunningham, S. A., Kanzow, T., Rayner, D., Baringer, M. O., Johns, W. E., Marotzke, J., Longworth, H. R., Grant, E. M., Hirschi, J. J., Beal, L. M., Meinen, C. S., and Bryden, H. L.: Temporal Variability of the Atlantic Meridional Overturning Circulation at $26.5^{\circ} \mathrm{N}, 317,935-938,2007$. 
Ekman, V. W.: On the influence of the earth's rotation on oceancurrents, Arkiv för matematik, astronomi och fysik, Bd. 2, no. 11., 68 pp., 1905.

Elipot, S. and Gille, S. T.: Estimates of wind energy input to the Ekman layer in the Southern Ocean from surface drifter data, J. Geophys. Res. Ocean., 114, 1-14, https://doi.org/10.1029/2008JC005170, 2009.

EU Copernicus: Wind: The L4 near-real-time wind stress data from Copernicus Marine Environment Monitoring Service, EU Commission, available at: https://marine.copernicus.eu, last access: 20 September 2016.

Fairall, C. W., Bradley, E. F., Hare, J. E., Grachev, A. A., and Edson, J. B.: Bulk parameterization of air-sea fluxes: Updates and verification for the COARE algorithm, J. Climate, 16, 571-591, https://doi.org/10.1175/15200442(2003)016<0571:BPOASF>2.0.CO;2, 2003.

Fischer, J., Brandt, P., Dengler, M., Müller, M., and Symonds, D.: Surveying the upper ocean with the Ocean Surveyor: A new phased array Doppler current profiler, J. Atmos. Ocean. Tech., 20, 742-751, https://doi.org/10.1175/15200426(2003)20<742:STUOWT>2.0.CO;2, 2003.

Friedrichs, M. A. M. and Hall, M. M.: Deep circulation in the tropical North Atlantic, J. Mar. Res., 51, 697-736, https://doi.org/10.1357/0022240933223909, 1993.

Fu, Y., Karstensen, J., and Brandt, P.: Physical oceanography and meteorology during METEOR cruises M96, M97 and M98, https://doi.org/10.1594/PANGAEA.870516, 2017.

Ganachaud, A. and Wunsch, C.: Large-Scale Ocean Heat and Freshwater Transports during the World Ocean Circulation Experiment, J. Climate, 16, 696-705, https://doi.org/10.1175/15200442(2003)016<0696:LSOHAF>2.0.CO;2, 2003.

Garzoli, S. L. and Molinari, R. L.: Ageostrophic transport in the upper layers of the tropical Atlantic Ocean, Geophys. Res. Lett., 28, 4619-4622, https://doi.org/10.1029/2001GL013473, 2001.

Hood, E. M., Sabine, C. L., and Sloyan, B. M.: GO-SHIP Repeat Hydrography Manual: A Collection of Expert Reports and Guidelines, IOCCP Report No. 14, ICPO Publication Series No. 134, available at: http://www.go-ship.org/HydroMan.html (last access: 8 August 2016), 2010.

Kanzow, T., Cunningham, S. A., Johns, W. E., Hirschi, J. J.M., Marotzke, J., Baringer, M. O., Meinen, C. S., Chidichimo, M. P., Atkinson, C., Beal, L. M., Bryden, H. L. and Collins, J.: Seasonal Variability of the Atlantic Meridional Overturning Circulation at $26.5^{\circ} \mathrm{N}$, J. Climate, 23, 5678-5698, https://doi.org/10.1175/2010JCLI3389.1, 2010.

Klein, B., Molinari, R. L., Müller, T. J., and Siedler, G.: A transatlantic section at $14.5 \mathrm{~N}$ : Meridional volume and heat fluxes, J. Mar. Res., 53, 929-957, https://doi.org/10.1357/0022240953212963, 1995.

Köhl, A.: Evaluation of the GECCO2 ocean synthesis: transports of volume, heat and freshwater in the Atlantic, Q. J. Roy. Meteor. Soc., 141, 166-181, https://doi.org/10.1002/qj.2347, 2015.

Large, W. G. and Pond, S.: Open ocean momentum flux measurements in moderate to strong winds, J. Phys. Oceanogr., 11, 324-336, https://doi.org/10.1175/15200485(1981)011<0324:OOMFMI>2.0.CO;2, 1981.

Large, W. G. and Yeager, S. G.: Diurnal to decadal global forcing for ocean and sea-ice models: The data sets and flux climatologies, NCAR Technical Note NCAR/TN-460+STR, https://doi.org/10.5065/D6KK98Q6, 2004.

Larson, N. and Pedersen, A. M.: Temperature measurements in flowing water: Viscous heating of sensor tips, Proceedings of 1st IGHEM Meeting, Montreal, QC, Canada, June 1996, available at: http://www.seabird.com/viscous-heating-sensor-tips (last access: 8 August 2016), 1996.

Lenn, Y. and Chereskin, T. K.: Observations of Ekman Currents in the Southern Ocean, J. Phys. Oceanogr., 39, 768-779, https://doi.org/10.1175/2008JPO3943.1, 2009.

Levitus, S.: Meridional Ekman Heat Fluxes for the World Ocean and Individual Ocean Basins, J. Phys. Oceanogr., 17, 1484-1492, https://doi.org/10.1175/15200485(1987)017<1484:MEHFFT>2.0.CO;2, 1987.

Locarnini, R. A., Mishonov, A. V., Antonov, J. I., Boyer, T. P., Garcia, H. E., Baranova, O. K., Zweng, M. M., Paver, C. R., Reagan, J. R., Johnson, D. R., Hamilton, M., and Seidov, D.: World Ocean Atlas 2013, Volume 1: Temperature, edited by: Levitus, S., technically edited by: Mishonov, A., NOAA Atlas NESDIS 73, 40 pp., 2013.

Lueck, R. G. and Picklo, J. J.: Thermal Inertia of Conductivity Cells: Observations with a Sea-Bird Cell, J. Atmos. Ocean. Tech., 7, 756-768, https://doi.org/10.1175/15200426(1990)007<0756:TIOCCO>2.0.CO;2, 1990.

Mason, E., Colas, F., Molemaker, J., Shchepetkin, A. F., Troupin, C., McWilliams, J. C., and Sangrà, P.: Seasonal variability of the Canary Current: A numerical study, J. Geophys. Res., 116, C06001, https://doi.org/10.1029/2010JC006665, 2011.

McCarthy, G., Frajka-Williams, E., Johns, W. E., Baringer, M. O., Meinen, C. S., Bryden, H. L., Rayner, D., Duchez, A., Roberts, C., and Cunningham, S. A.: Observed interannual variability of the Atlantic meridional overturning circulation at $26.5^{\circ} \mathrm{N}$, Geophys. Res. Lett., 39, 1-5, https://doi.org/10.1029/2012GL052933, 2012.

McCarthy, G. D., Smeed, D. A., Johns, W. E., Frajka-Williams, E., Moat, B. I., Rayner, D., Baringer, M. O., Meinen, C. S., Collins, J., and Bryden, H. L.: Measuring the Atlantic Meridional Overturning Circulation at $26^{\circ} \mathrm{N}$, Prog. Oceanogr., 130, 91-111, https://doi.org/10.1016/j.pocean.2014.10.006, 2015.

McDonagh, E. L., King, B. A., Bryden, H. L., Courtois, P., Szuts, Z., Baringer, M., Cunningham, S. A., Atkinson, C., and McCarthy, G.: Continuous estimate of Atlantic oceanic freshwater flux at $26.5^{\circ} \mathrm{N}$, J. Climate, 28, 8888-8906, https://doi.org/10.1175/JCLI-D-14-00519.1, 2015.

McDougall, T. J. and Barker, P. M.: Getting started with TEOS10 and the Gibbs Seawater (GSW) Oceanographic Toolbox, SCOR/IAPSO WG127, 28 pp., available at: http://www.teos-10. org/pubs/Getting_Started.pdf (last access: 10 August 2016), 2011.

Montgomery, R. B.: Comments on "Seasonal variability of the Florida Current", by Niiler and Richardson, J. Mar. Res., 32, 533-535, 1974.

National Centers for Environmental Prediction/National Weather Service/NOAA/U.S. Department of Commerce: NCEP/NCAR Reanalysis Monthly Mean Subsets (from DS090.0), 1948continuing, Research Data Archive at the National Center for Atmospheric Research, Computational and Information Systems Laboratory, available at: http://rda.ucar.edu/datasets/ds090. 2/ (last access: 20 September 2016), 1996 (updated monthly). 
Pérez-Hernández, M. D., McCarthy, G. D., Vélez-Belchí, P., Smeed, D. A., Fraile-Nuez, E., and Hernández-Guerra, A.: The Canary Basin contribution to the seasonal cycle of the Atlantic Meridional Overturning Circulation at $26^{\circ} \mathrm{N}, \mathrm{J}$. Geophys. Res.-Oceans, 120, 7237-7252, https://doi.org/10.1002/2015JC010969, 2015.

Price, J. F., Weller, R. A., and Schudlich, R. R.: Wind-Driven Ocean Currents and Ekman Transport, Science, 238, 1534-1538, https://doi.org/10.1126/science.238.4833.1534, 1987.

Rabe, B., Schott, F. A., and Köhl, A.: Mean Circulation and Variability of the Tropical Atlantic during 1952-2001 in the GECCO Assimilation Fields, J. Phys. Oceanogr., 38, 177-192, https://doi.org/10.1175/2007JPO3541.1, 2008.

Roemmich, D. and Gilson, J.: The 2004-2008 mean and annual cycle of temperature, salinity, and steric height in the global ocean from the Argo Program, Prog. Oceanogr., 82, 81-100, https://doi.org/10.1016/j.pocean.2009.03.004, 2009.

Rudnick, D. L. and Klinke, J.: The underway conductivitytemperature-depth instrument, J. Atmos. Ocean. Tech., 24, 19101923, https://doi.org/10.1175/JTECH2100.1, 2007.

Saha, S., Moorthi, S., Pan, H.-L., Wu, X., Wang, J., Nadiga, S., Tripp, P., Kistler, R., Woollen, J., Behringer, D., Liu, H., Stokes, D., Grumbine, R., Gayno, G., Wang, J., Hou, Y.-T., Chuang, H.Y., Juang, H.-M. H., Sela, J., Iredell, M., Treadon, R., Kleist, D., Van Delst, P., Keyser, D., Derber, J., Ek, M., Meng, J., Wei, H., Yang, R., Lord, S., van den Dool, H., Kumar, A., Wang, W., Long, C., Chelliah, M., Xue, Y., Huang, B., Schemm, J.-K., Ebisuzaki, W., Lin, R., Xie, P., Chen, M., Zhou, S., Higgins, W., Zou, C.-Z., Liu, Q., Chen, Y., Han, Y., Cucurull, L., Reynolds, R. W., Rutledge, G., and Goldberg, M.: NCEP Climate Forecast System Reanalysis (CFSR) 6-hourly Products, January 1979 to December 2010, Research Data Archive at the National Center for Atmospheric Research, Computational and Information Systems Laboratory, https://doi.org/10.5065/D69K487J, 2010.

Sato, O. T. and Polito, P. S.: Comparison of the Global Meridional Ekman Heat Flux Estimated from Four Wind Sources, J. Phys. Oceanogr., 35, 94-108, https://doi.org/10.1175/JPO2665.1, 2005.

Schott, F. A., Dengler, M., Zantopp, R., Stramma, S., Fischer, J., and Brandt, P.: The Shallow and Deep Western Boundary Circulation of the South Atlantic at $5^{\circ}-11^{\circ} \mathrm{S}$, J. Phys. Oceanogr., 35, 20312053, https://doi.org/10.1175/JPO2813.1, 2005.

Schott, F. A., Mccreary, J. P., and Johnson, G. C.: Shallow Overturning Circulations of the Tropical-Subtropical Oceans, in: Earth's Climate, edited by: Wang, C., Xie, S. P., and Carton, J. A., American Geophysical Union, Washington, D.C., 261-304, https://doi.org/10.1029/147GM15, 2004.
Smith, S. D.: Coefficients for sea surface wind stress, heat flux, and wind profiles as a function of wind speed and temperature, J. Geophys. Res., 93, 15467-15472, https://doi.org/10.1029/JC093iC12p15467, 1988.

Smyth, W. D., Durland, T. S., and Moum, J. N.: Energy and heat fluxes due to vertically propagating Yanai waves observed in the equatorial Indian Ocean, J. Geophys. Res.-Oceans, 120, 1-15, https://doi.org/10.1002/2014JC010152, 2015.

Talley, L. D., Pickard, G. L., Emery, W. J., and Swift, J. H.: Descriptive Physical Oceanography: an introduction, 6th Edn., Elsevier, 555 pp., 2011.

Ullman, D. S. and Hebert, D.: Processing of underway CTD data, J. Atmos. Ocean. Tech., 31, 984-998, https://doi.org/10.1175/JTECH-D-13-00200.1, 2014.

Wang, W. and Huang, R.: Wind Energy Input to the Ekman Layer*, J. Phys. Oceanogr., 34, 1267-1275, https://doi.org/10.1175/15200485(2004)034<1267:WEITTE>2.0.CO;2, 2004.

Watanabe, M. and Hibiya, T.: Global estimates of the wind-induced energy flux to inertial motions in the surface mixed layer, Geophys. Res. Lett., 29, 1239, https://doi.org/10.1029/2001GL014422, 2002.

Wijffels, S., Firing, E., and Bryden, H.: Direct Observations of the Ekman Balance at $10^{\circ} \mathrm{N}$ in the Pacific, J. Phys. Oceanogr., 24, 1666-1679, https://doi.org/10.1175/15200485(1994)024<1666:DOOTEB>2.0.CO;2, 1994.

Wijffels, S. E., Toole, J., and Bryden, H.: The water masses and circulation at $10^{\circ} \mathrm{N}$ in the Pacific, Deep-Sea Res. Pt. I, 43, 501544, https://doi.org/10.1016/0967-0637(96)00006-4, 1996.

Wunsch, C. and Heimbach, P.: Estimated Decadal Changes in the North Atlantic Meridional Overturning Circulation and Heat Flux 1993-2004, J. Phys. Oceanogr., 36, 2012-2024, https://doi.org/10.1175/JPO2957.1, 2006.

Zhang, J. and Rothrock, D.: Modeling Arctic sea ice with an efficient plastic solution, J. Geophys. Res., 105, 3325, https://doi.org/10.1029/1999JC900320, 2000.

Zweng, M. M., Reagan, J. R., Antonov, J. I., Locarnini, R. A., Mishonov, A. V., Boyer, T. P., Garcia, H. E., Baranova, O. K., Johnson, D. R., Seidov, D., and Biddle, M. M.: World Ocean Atlas 2013, Volume 2: Salinity, edited by: Levitus, S., technically edited by: Mishonov, A., NOAA Atlas NESDIS 74, 39 pp., 2013. 